\title{
Sulfidic spring in the gypsum karst system of Monte Conca (Italy): chemistry and microbiological evidences
}

\author{
Marianna Messina*1, Tiziana Grech ${ }^{1}$, Fiorenzo Fiorenza ${ }^{1}$, Alessandro Marletta ${ }^{1,3}$, \\ Pietro Valenti ${ }^{2}$, and Salvatore Petralia ${ }^{* 1,4}$ \\ ${ }^{1}$ Centro Speleologico Etneo, Via Valdisavoia 3, 95123, Catania, Italy \\ ${ }^{2}$ Associazione Sportiva Dilettantistica Naturalistica Siciliana Nisida, via Tramontana 28, 90144 Palermo, Italy \\ ${ }^{3}$ Department of Biological, Geological and Enviromental Sciences - Section of Animal Biology, "M. La Greca" University of Catania, \\ Via Androne 81, 95124 Catania, Italy \\ ${ }^{4}$ Applied Chemical Works, Tremestieri Etneo (Ct), Italy
}

\begin{abstract}
Monte Conca Cave is a karst system placed in Messinian evaporites, consisting of an active cave and a resurgence located on the massif of Monte Conca, Campofranco within the "Riserva Naturale Integrale di Monte Conca". A sulfidic spring is located in the terminal gallery of the cave. To characterize the physical and chemical parameters of the Monte Conca Cave and of the sulfidic spring, air temperature, relative humidity, water $\mathrm{pH}$, and concentrations of dissolved sulfides, nitrates and sulfates were monitored. The high sulfide consumption rate in the sulfidic spring, evaluated by a kinetic study, suggests that biotic consumption is dominant. Moreover, snottites and filamentous floating mats, rich in sulfur and nitrate suggest a microbial activity related to the sulfur cycle. Iron content was also evaluated in water and snottites, given its involvement in microbial activity. The microbial mats could be the source of an autotrophic system in close correlation with the biological cycle of many species of living organisms found near the spring. Some of them show typical troglobitic characteristics, while the presence and abundance of others depends on the water amount. The greater abundance of taxa found close to the sulfidic spring suggests a complex food web associated with it. The monitoring lasted a year and half has highlighted the difference between chemical- physical parameters of the cave and the sulfidic spring, emphasizing its typical microenvironment.
\end{abstract}

Keywords: $\quad$ sulfidic spring; cave; snottites; microbial mats; monitoring; Monte Conca; Italy

Received 20 June 2014; Revised 8 January 2015; Accepted 8 January 2015

Citation: Messina M., Grech T., Fiorenza F., Marletta A., Valenti P. and Petralia S., 2015. Sulfidic spring in the gypsum karst system of Monte Conca (Italy): chemistry and microbiological evidences. International Journal of Speleology, 44 (2), 125-139. Tampa, FL (USA) ISSN 0392-6672 http://dx.doi.org/10.5038/1827-806X.44.2.3

\section{INTRODUCTION}

The explorations and the scientific investigations of sulfide-rich caves have advanced the knowledge on the development of karst systems. Multi-disciplinary teams have recognized the importance of hydrogen-sulfide on the geochemistry and microbiology of these systems.

Principi (1931) first proposed sulfuric acid-driven speleogenesis and suggested that some caves were created by the interaction of sulfidic waters with limestone. Galdenzi \& Maruoka (2003) reported that many limestone caves contain small gypsum deposits formed by evaporation of sulfate-rich water on cave fills or walls. Moreover, they described the morphologic effects of the oxidation of $\mathrm{H}_{2} \mathrm{~S}$ for the Frasassi Cave, where the limestone walls, exposed to the $\mathrm{H}_{2} \mathrm{~S}$ vapors, are highly corroded and partially or completely covered by gypsum crusts. Hose \& Pisarowicz (1999) reported
Cueva de Villa Luz as a striking example of sulfur-related speleogenesis and a chemoautotrophic ecosystem. In Movile Cave, Romania (Sarbu et al., 1996), performed the first complex study of a sulfidic underground ecosystem based on chemosynthesis, and report sulfuric acid speleogenesis, including sulfur stable isotope data.

Other authors described sulfuric acid speleogenesis and presence of microbial mats also in U.S. caves (Angert et al., 1998; Engel et al., 2001; Engel et al., 2003; Engel et al., 2004). Moreover, Galdenzi et al. (2008) reported an interesting study on the influence of the cave environment and speleogenesis by composition of sulfidic groundwater. By monitoring the chemical parameters of the water, they explained how the seasonal changes in water chemistry interact with the cave speleogenesis. The authors showed that sulfidic groundwater contains both oxidized and reduced sulfur species with significant variation 
during the year. The drastic increase of the $\mathrm{H}_{2} \mathrm{~S}$ concentration in the spring water was also correlated to the activity of sulfate-reducing-bacteria, identified by Macalady et al. (2006). These bacteria live closely associated with sulfide oxidizing bacteria in the microbial films that cover the water surface.

Engel (2000) published a list of known active sulfidic caves, documented sulfur-oxidizing microorganisms, and explored the biodiversity of sulfidic caves and karst ecosystems distributed worldwide and containing sulfidic springs (Engel, 2007). The same author reported that a wide range of microorganisms live in sulfidic waters and a vast majority of them are sulfur-oxidizing bacteria inhabiting the cave spring and the streams, as well as the cave walls. Some of these bacteria are shown to be acidophilic due to the production of sulfuric acid. All sites with microbial evidences and containing sulfidic springs reported in literature are limestone cave systems, whereas very few gypsum caves are known to have microbial evidences. Recently, Cacchio et al. (2012) investigated the involvement of bacteria in the formation of a new type of speleothems from Grave Grubbo Cave (Italy). This is the first report on sulfidic spring water and its environment in a gypsum karst system: Monte Conca Cave (Italy).

The intense explorations of the Monte Conca Cave in the last two decades and the discovery of its sulfidic spring, prompted us to evaluate their chemical-physical parameters in various hydrogeological and climate conditions (wet and dry seasons). The investigation also provided some evidence of the presence of microbial communities associated with the sulfidic conditions. The presence of snottites, typical structures of the sulfidic spring environment, has been investigated and documented for the first time in the Monte Conca Cave. Furthermore, chemical analysis has shown the presence of iron and sulfur deposits that could be involved in microbiological activity, as described in literature (Hose et al., 2000; Dopson \& Johnson, 2012).

The preliminary results of the faunistic monitoring have shown the presence of invertebrate species closely correlated with the microbial life of the sulfidic spring. The experimental results documented the presence of more than 50 species belonging to different phyla. Among these, some show typical troglobitic characteristics, while the presence of others depends on the cave water amount.

\section{SITE DESCRIPTION}

The Monte Conca Cave is the longest and deepest gypsum karst system in Sicily. It is located in Messinian evaporites in central-western Sicily and consist of an active sink cave (Inghiottitoio di Monte Conca), a resurgence (Risorgenza di Monte Conca) and a relict resurgence (Paleorisorgenza di Monte Conca), as decribed by Madonia and Vattano (2011). The "Inghiottitoio di Monte Conca" is formed by an upper gallery, about $100 \mathrm{~m}$ long, developed along the N-S and NW-SE oriented fractures. Following this gallery there is a sequence of four waterfalls: $11,12,35$, and 26 deep respectively. The lower gallery, about $450 \mathrm{~m}$ long, is developed from the base of the last shaft. Additional sub-horizontal galleries, about $1.5 \mathrm{~km}$ long, were discovered between 2003 and 2008 (Madonia \& Vattano 2011). Figures 1 and 2 show the location of the sulfidic-spring on the plan and the profile views of the cave.

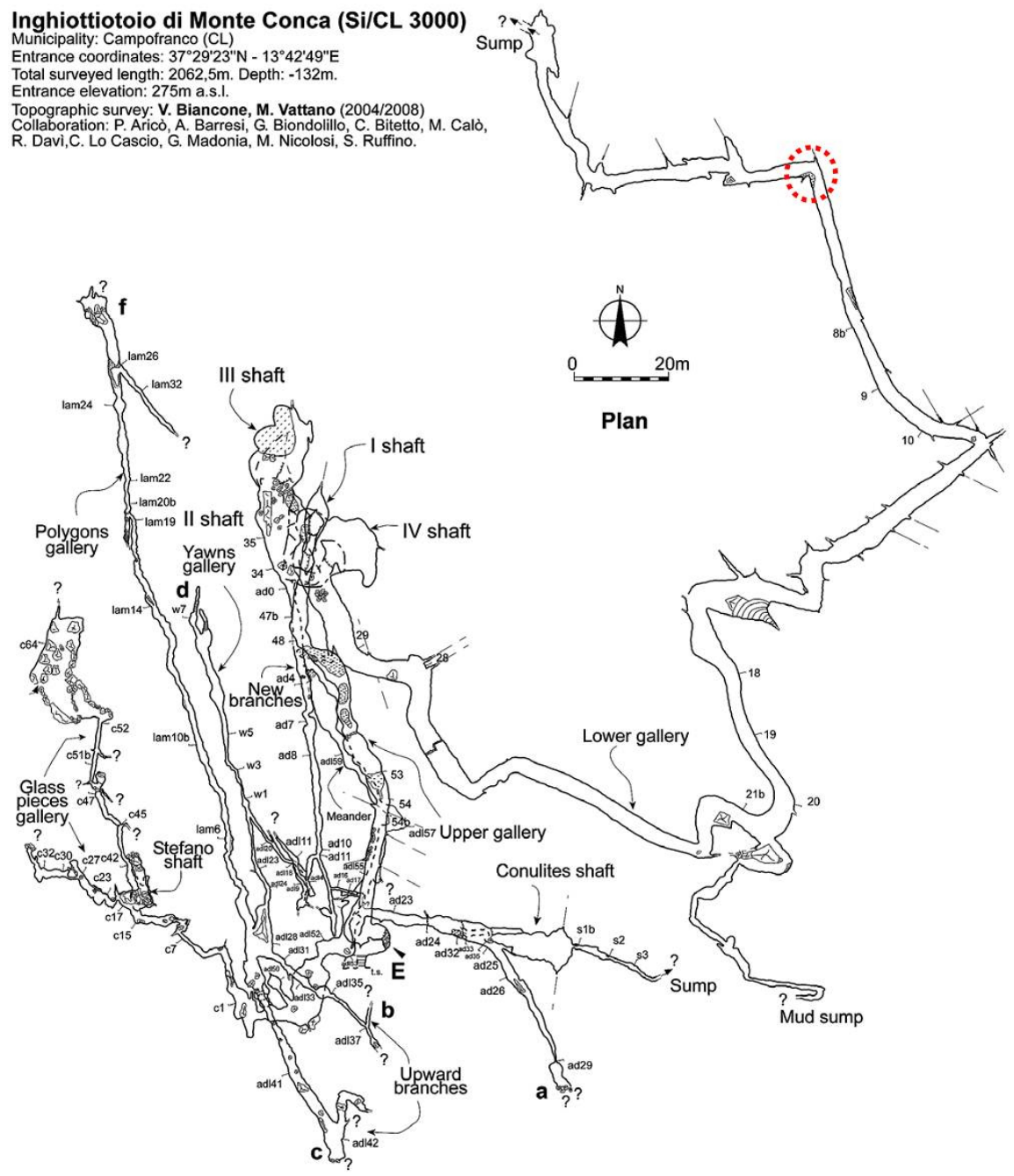

Fig. 1. Cave map of the Inghiottitoio di Monte Conca: plan. In red dash circle the location of the sulfide-spring (from Madonia \& Vattano, 2011).

The cave formation was explained by a morphoevolution model proposed by Vattano and Madonia (2011). The sulfidic-spring (Fig. 3) is located in the inner part of the lower gallery and is characterized by different sediments such as clay, mud, gravel, and chemical deposits. The size of the spring varies according to the seasons. The smallest size recorded, in dry season, was about $2 \mathrm{~m}$ diameter and, at most, $50 \mathrm{~cm}$ deep. In dry season there is no flow of surface water into the cave and only small lakes are present under the shafts, therefore the sulfidic spring is not connected with these water bodies. During the wet season and after heavy rains, surface water reach the lower gallery 


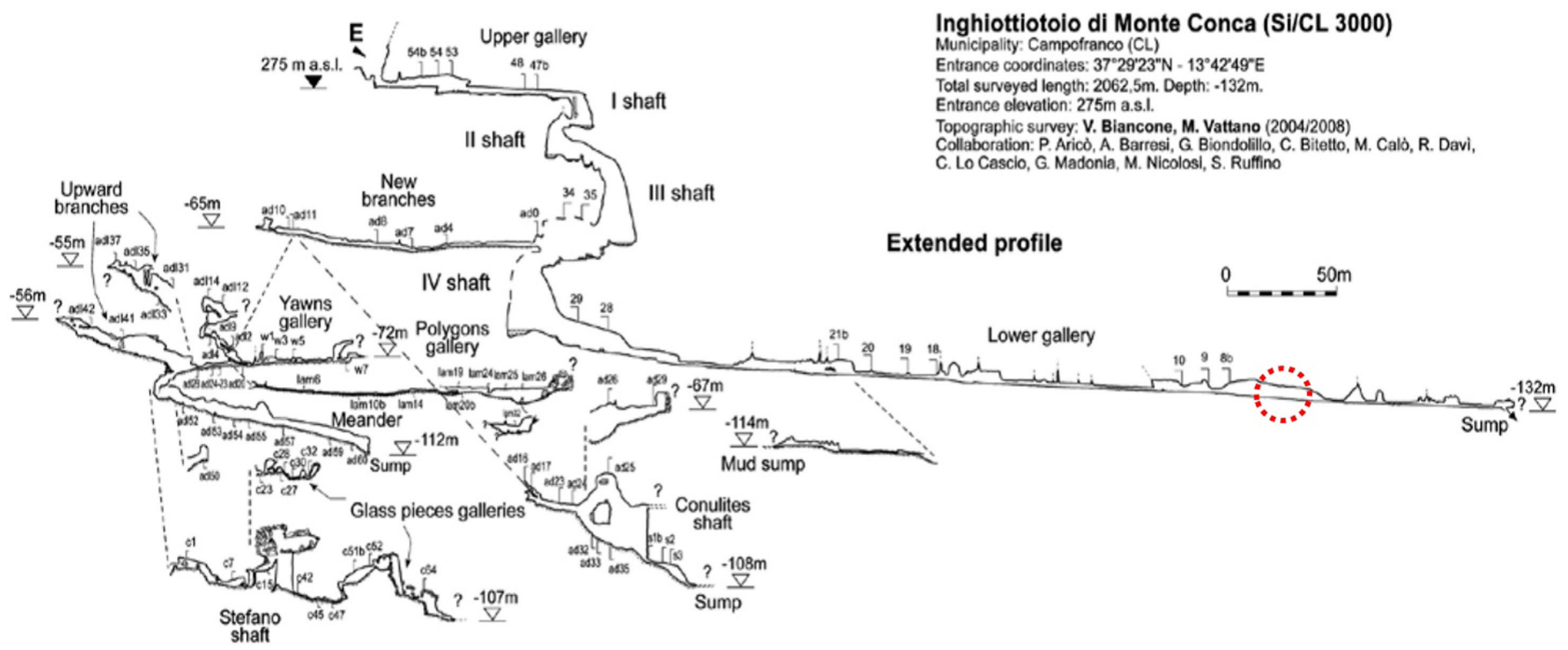

Fig. 2. Cave map of the Inghiottitoio di Monte Conca: extended profile. In red dash circle the location of the sulfide-spring (from Madonia \& Vattano, 2011).

and may flood the sulfidic spring. A little sulfidic stream with an estimated flow rate of about $11 /$ sec is generated by the sulfidic spring and it persists during the dry season too. This stream, about 60 meters long, flows into the final sump of the lower gallery. It still maintains the main features of the sulfidic spring, such as filamentous mats, iron deposits, and suspended sulfur folia or gypsum mineralizations.

A typical smell of hydrogen sulfide is permanent in the inner part of the lower gallery.

Nearby and inside the sulfidicspring some black and orange mineralization deposits were discovered, and their sampling and subsequent chemical analysis have confirmed the presence of iron as

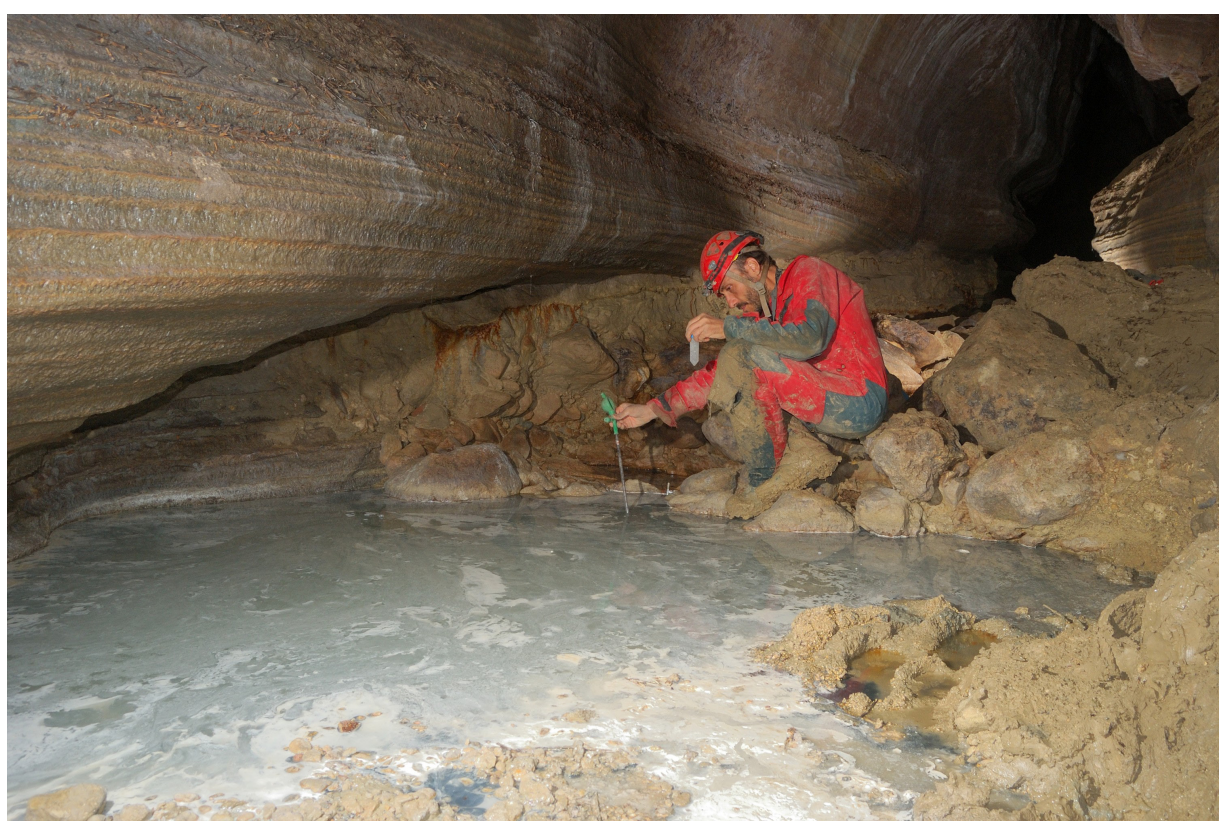

Fig. 3. Sulfidic spring containing the characteristic white microbial mats floating on water surface, sulfur suspensions, as well as black and red deposits (photo by F. Fiorenza). the main element. The genesis of the mineralization deposits is under investigation at present. Peck (1986) described the presence of microbial species in iron and manganese oxides within the caves and proposed the possibility of the chemolithotrophic primary producers in these systems. The presence of microbial species in the Monte Conca Cave was also confirmed by "organic stalactites" commonly known as Snottites, present on the walls and the ceilings, as also described by Galdenzi \& Maruoka (2003) in the Frasassi Cave and by Hose and Pisarowich (1999) in the Cueva de Villa Luz. These microbial deposits, can grow and cover the walls with a layer of organic mucous matter, secreting acid drops, rich in $\mathrm{H}_{2} \mathrm{SO}_{4}$, with $\mathrm{pH}$ values lower than one.

\section{MATERIALS AND METHODS}

\section{Chemical-physical measurements}

The measurements were carried out between May 2012 and November 2013, in both dry and wet seasons. Sampling and measurements were skipped during some wet periods due to the high water flow in the cave.

\section{Air physical parameters}

Cave's air temperature (T) and relative humidity (RH) measurements were performed using a HOBOware sensor (sensitivity, $\mathrm{s}, 0.01^{\circ} \mathrm{C}$ ). Table 1 lists average temperature values above the sulfidic spring and along the cave, excluding the entrance gallery that is affected by external temperature. Figure 4 displays an example of sensor measurement performed in July 2012 during the run of cavers.

\section{Water chemistry and chemical-physical parameters}

Water temperature was monitored by mercury thermometer $\left(\mathrm{s} 0.5^{\circ} \mathrm{C}\right)$ and the values are reported in Table 1. Similarly to the air monitoring, the water temperature average values were calculated excluding the water temperature values of the entrance gallery, very close to temperature of external water stream, that is channelled in the cave. 


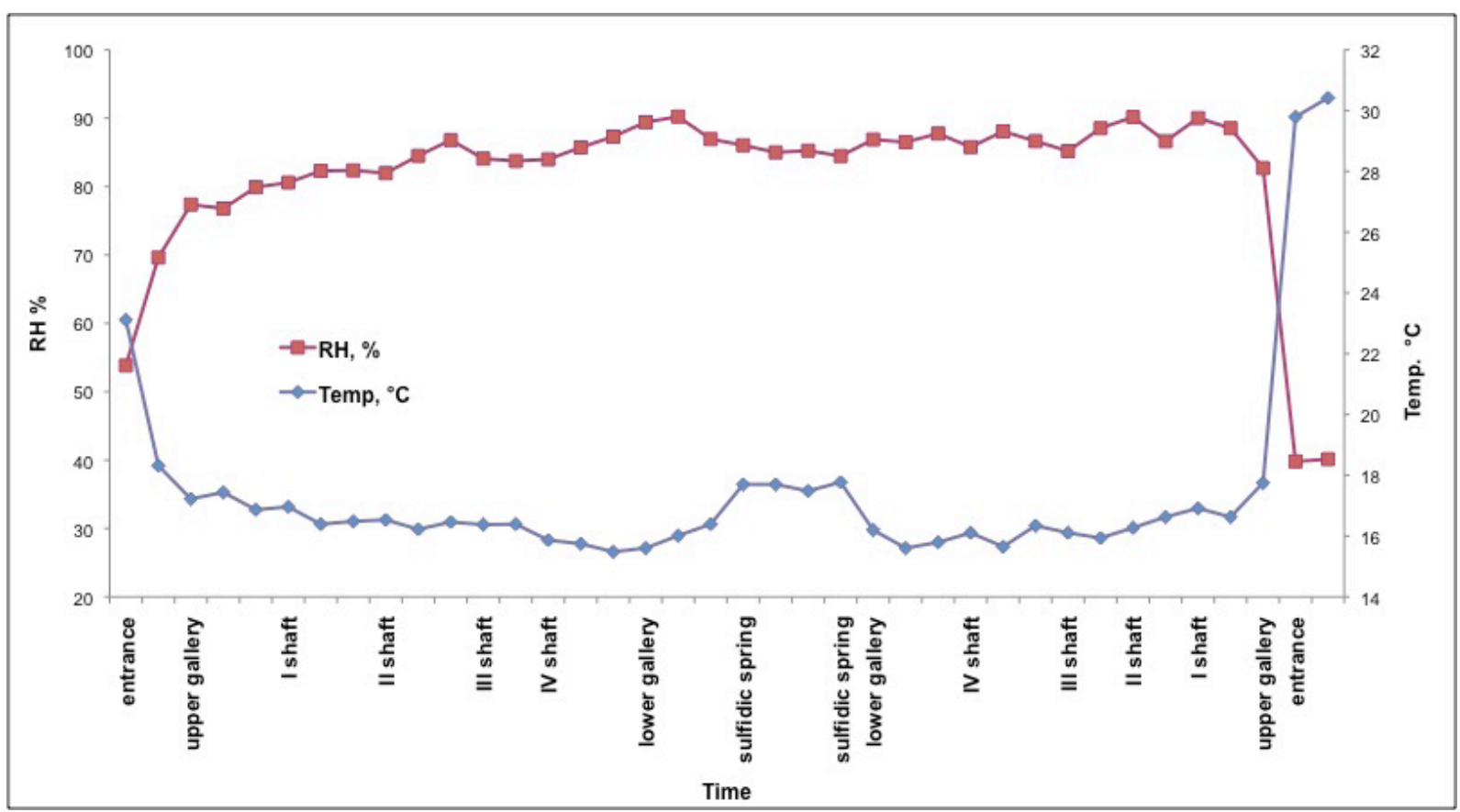

Fig. 4. Air temperature $\left({ }^{\circ} \mathrm{C}\right)$ and relative humidity $(\mathrm{RH}, \%)$ trends monitored along the entire cave in July 2012. Data points represent the principal places of the measurement.

The $\mathrm{pH}$ measurements in situ were carried out with Carlo Erba $\mathrm{pH}$ indicator strips ( $\mathrm{s}=0.3$ unit of $\mathrm{pH}$ ) and with a Mettler-Toledo FiveEasy ${ }^{\mathrm{TM}}$ pHmeter ( $\mathrm{s}=0.01$ unit of $\mathrm{pH}$ ) in laboratory.

The sulfate concentrations, expressed as barium sulfate $\left(\mathrm{BaSO}_{4}\right)$, were determined in laboratory by turbidimetry (Molecular Devices SpectraMax ${ }^{\circledR}$ spectrophotometer) using a linear regression method and confirmed by ionic chromatography (Metrohm). For turbidimetric analysis, amounts of barium chloride solution were added in situ to water samples, after acidification at $\mathrm{pH}<2$ to prevent $\mathrm{BaCO}_{3}$ precipitation, in order to obtain the stable compound barium sulfate.

Table 1 describes the average values of sulfate amounts for the sulfidic-spring and the cave.

The concentrations of sulfide, expressed as hydrogen sulfide $\left(\mathrm{H}_{2} \mathrm{~S}\right)$, were measured in the laboratory using the spectrophotometric methylene blue method reviewed by Cline (1969) (LOD = $0.0084 \mathrm{ppm}, \mathrm{LOQ}=0.028 \mathrm{ppm}$ ) with

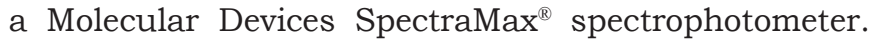
The water samples were collected from June 2012 to November 2013.

Two aliquots were collected for each sampling point. The first aliquot was left as is. Zinc acetate (Sigma) was added to the other one in order to precipitate zinc sulfide $(\mathrm{ZnS})$, a sulfur stable compound that can be easily transported and analysed in the laboratory for quantitative determinations. Furthermore, in order to investigate the sulfide distribution versus the spring water depth, three different sub-aliquots were sampled at three different depths (at the surface, $15 \mathrm{~cm}$, and $30 \mathrm{~cm}$ deep). $\mathrm{H}_{2} \mathrm{~S}$ concentration for the stabilized water samples are reporetd in Table 1. The water samples that were not stabilized showed negligible amount of $\mathrm{H}_{2} \mathrm{~S}$.

From May to July 2012, the sulfide sampling and measurements were performed in different points of the cave: entrance, small lakes at the base of the four shafts, in the middle of lower gallery and in the sulfidic-spring. As no sulfide was detected for the first four sampling points, for the following months we focused our efforts to sample and measure only in the lake at the base of last shaft, in the middle of lower gallery and in the sulfidic-spring.

In July 2013, water samples were collected throughout the cave and in the sulfidic spring in order to evaluate the water hardness and conductivity as well as the concentrations of the main ions, by ionic chromatography (Table 2). The presence of nitrate and sulfur in microbial mats was also evaluated by mass spectrometry. Quadrupole mass spectrometer (WATERS) equipped with electrospray ionization (ESI) interface were used for data acquisition.

\section{Microbiological evidences}

As widely described in literature for different caves containing sulfidic-spring the presence of biofilms that hang from the walls and ceilings above spring and the filamentous white mats that float on the sulfidic water surface, are evidence of the presence of bacteria (Hose et al., 2000; Barton \& Northup, 2005; Hose \& Macalady, 2006; Engel, 2007; Jones et al., 2008; Jones et al., 2011; Dopson \& Johnson, 2012). Iron deposits, elemental sulfur suspension or folia, gypsum deposits, peculiar microclimate and chemical parameters were also reported as combination of typical features that indicate microbiological activity. (Hose et al., 2000; Hose \& Macalady, 2006; Engel, 2007; Galdenzi et al., 2008; Dopson \& Johnson, 2012).

\section{Iron deposits}

Black deposits and reddish-orange percolates in the sulfidic-spring area have suggested the presence of iron compounds, respectively, as iron (II) sulfide and iron (III) oxides (Fig. 5). Ionic iron identification was carried out by specific thiocyanate spectrophotometric assay. 
Table 1. Monitoring of chemical-physical parameters in the cave and spring of Monte Conca.

\begin{tabular}{|c|c|c|c|c|c|c|c|c|c|c|}
\hline & \multicolumn{2}{|c|}{ Air $\mathrm{T}\left({ }^{\circ} \mathrm{C}\right)$} & \multicolumn{2}{|c|}{ Water $\mathbf{T}\left({ }^{\circ} \mathrm{C}\right)$} & \multicolumn{2}{|c|}{ pH } & \multicolumn{2}{|c|}{$\mathbf{H}_{2} \mathbf{S} \mathbf{p p m}$} & \multicolumn{2}{|c|}{$\mathrm{BaSO}_{4} \mathrm{ppm}$} \\
\hline & cave & spring & cave & spring & cave & spring & cave & spring & cave & spring \\
\hline May 12 & 15.5 & 16.8 & 13.0 & 16.0 & - & - & - & - & - & - \\
\hline Jun 12 & 15.26 & 16.68 & 13.5 & 16.0 & 7.6 & 7.4 & 0.18 & 9.62 & - & - \\
\hline Jul 12 & 16.21 & 17.67 & 14.0 & 16.5 & 7.4 & 6.8 & - & 20.21 & - & - \\
\hline Aug 12 & 16.0 & 17.2 & 14.0 & 16.0 & 7.4 & 6.8 & 0.19 & 23.69 & 1,456 & 1,916 \\
\hline Sep 12 & 16.02 & 17.37 & 14.0 & 16.0 & 7.6 & 6.9 & 0.19 & 27.81 & 1,427 & 1,901 \\
\hline Jan 13 & 14.30 & 16.40 & 11.0 & 12.5 & 7.70 & 7.65 & 0.035 & 0.27 & 1,548 & 1,444 \\
\hline May 13 & 15.3 & 16.3 & 15.5 & 16.0 & 7.70 & 7.61 & 0.032 & 0.47 & 1,517 & 1,442 \\
\hline Jun 13 & 15.1 & 16.5 & 14.5 & 16.5 & 7.45 & 6.93 & 0.088 & 7.45 & 1,665 & 1,887 \\
\hline Jul 13 & 15.7 & 17.0 & 15.0 & 17.0 & 7.39 & 6.77 & 0.13 & 16.21 & 1,415 & 1,762 \\
\hline Sep 13 & 15.85 & 17.10 & 15.0 & 17.0 & 7.68 & 6.95 & 0.16 & 16.93 & 2,042 & 1,372 \\
\hline Nov 13 & 15.90 & 17.30 & 15.0 & 17.0 & - & - & - & 1.19 & - & - \\
\hline
\end{tabular}

Table 2. Main chemical parameters for cave and spring water of Monte Conca Cave.

\begin{tabular}{|c|c|c|c|c|c|c|c|c|c|c|c|}
\hline & $\begin{array}{c}\text { pH } \\
\text { (unit) }\end{array}$ & $\begin{array}{c}\text { Conductivity } \\
(\mu \mathrm{S} / \mathrm{cm})\end{array}$ & $\begin{array}{c}\text { Hardness } \\
\left({ }^{\circ} F\right)\end{array}$ & $\begin{array}{l}\mathrm{SO}_{4}{ }^{2-} \\
\text { (ppm) }\end{array}$ & $\begin{array}{c}\mathbf{S}^{2-} \\
\text { (ppm) }\end{array}$ & $\begin{array}{c}\mathrm{Cl}^{-} \\
\text {(ppm) }\end{array}$ & $\begin{array}{c}\mathrm{NO}_{3}^{-} \\
\text {(ppm) }\end{array}$ & $\begin{array}{c}\mathrm{Ca}^{2+} \\
\text { (ppm) }\end{array}$ & $\begin{array}{l}\mathrm{Mg}^{2+} \\
\text { (ppm) }\end{array}$ & $\begin{array}{c}\mathrm{Na}^{+} \\
\text {(ppm) }\end{array}$ & $\begin{array}{c}\mathbf{K}^{+} \\
\text {(ppm) }\end{array}$ \\
\hline cave & 7.5 & 3,341 & 178.6 & 1,435 & $<0.1$ & 162 & 3 & 601 & 69 & 139 & 4 \\
\hline spring & 6.9 & 3,415 & 208.4 & 1,862 & $<0.1$ & 149 & $<0.1$ & 656 & 108 & 113 & 25 \\
\hline
\end{tabular}
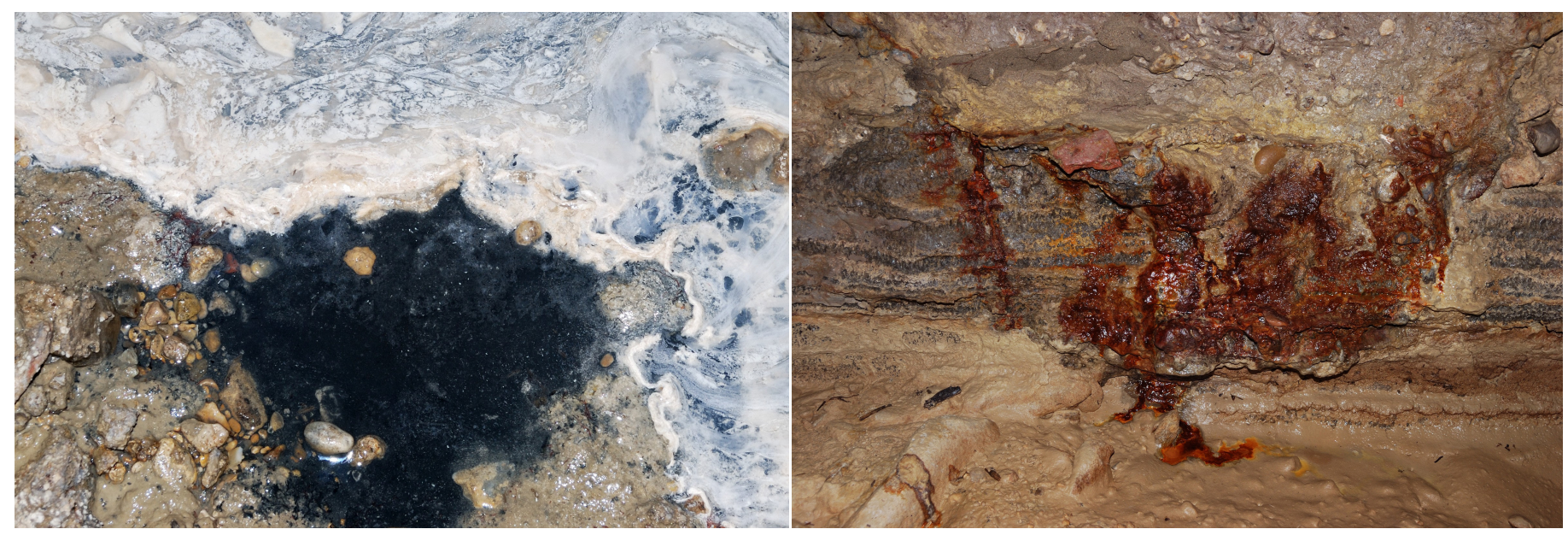

Fig. 5. left) Black iron deposit of FeS in sulfidic spring; right) Reddish iron deposits on walls and ceiling nearby the sulfidic spring (photo by F. Fiorenza).

\section{Sulfur deposits}

During the dry seasons, the water surface of the sulfidic spring accommodates a white-yellow deposit identified as elemental sulfur. The sulfur identification was carried out by specific test-tube with characteristic red vapor formation on the tube walls as a consequence of sulfur heating and later, formation of yellow sulfur deposits once the temperature drops. Moreover, in order to evaluate elemental sulfur in microbial mats, massspectrometry measurements were carried out. Elemental sulfur extraction from microbial mats was performed using the method reported by Hinch et al. (2007), Preisler et al. (2007), and properly revised. The extracted sulfur was identified as polysulfide intermediates by mass spectrometry as reported by Gun et al. (2004).

\section{Microbial mats}

White filamentous mats are floating on the surface of the sulfidic-spring (Fig. 6). These mats are floating on the surface of the sulfidic stream and they also cover the surface sediments. In some parts, of the sulfidic-spring, filamentous mats are present to a water depth of about $10 \mathrm{~cm}$.

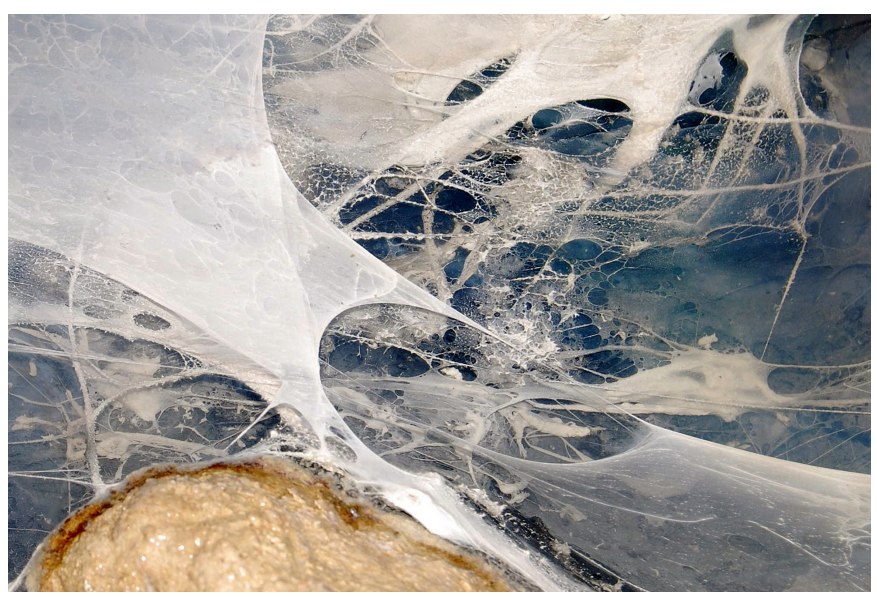

Fig. 6. Filamentous white microbial mat floating on the surface of the sulfidic-spring (photo by F. Fiorenza).

\section{Snottites}

Many limestone caves containing sulfidic water, show peculiar organic "stalactites" called snottites. They are usually few centimetres long, consisting of viscous microbial biofilms that grow and cover the walls and ceilings, secreting acidic drops, rich 
in sulfuric acid (Galdenzi et al., 1999a; Galdenzi et al., 1999b; Hose et al., 2000; Galdenzi \& Maruoka, 2003; Hose \& Macalady, 2006; Barton \& Northup, 2007; Macalady et al., 2007; Jones et al., 2011). In the Monte Conca Cave, snottites were found on the walls and ceiling around the sulfidic-spring area and the measured $\mathrm{pH}$ value of their drops ranged from 0.5 to 1.0 (Fig. 7). The presence of sulfuric acid in the distillate was confirmed by its precipitation as barium sulfate and by mass spectrometry measurements as reported by Campana \& Risby (1980) for sulfuric acid solutions.
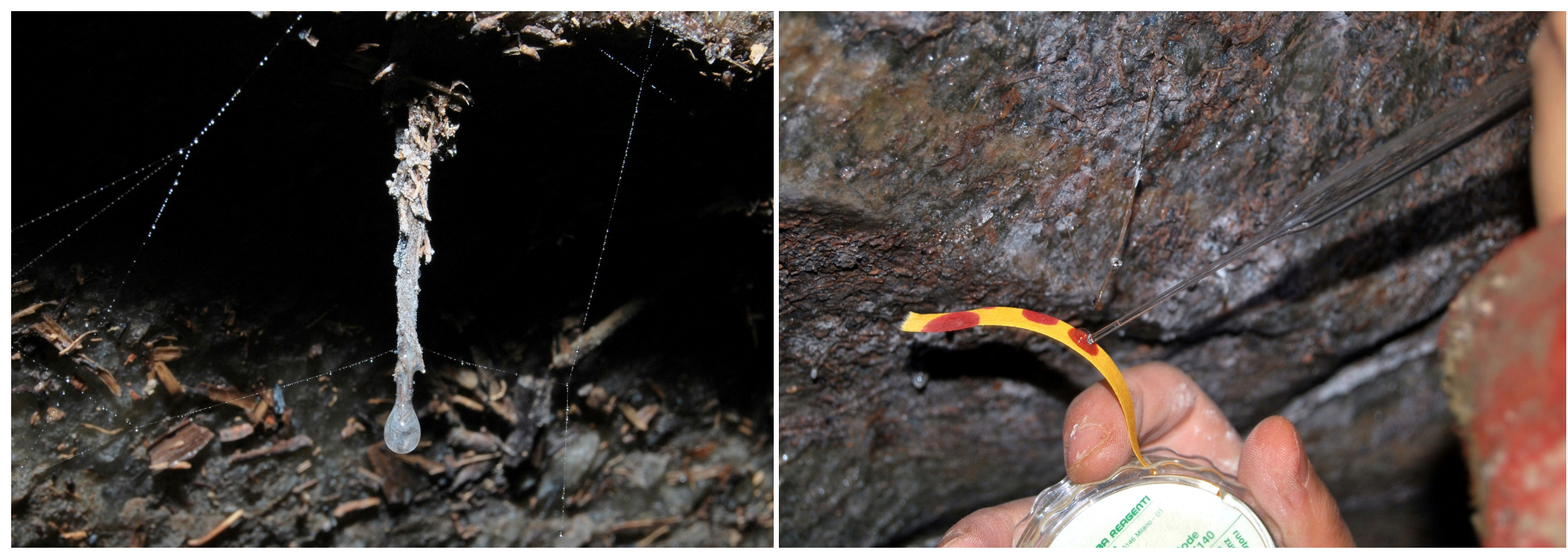

Fig. 7. Snottites on Monte Conca sulfidic spring: left) Snottites hanging from the ceiling; right) Sulfuric acid (pH 1) dripped from snottites (photo by F. Fiorenza).

\section{Sulfide consumption: kinetic studies}

The sulfide consumption in aqueous solutions can occur through two different pathways, abiotic $\left(\mathrm{H}_{2} \mathrm{~S}+2 \mathrm{O}_{2} \rightarrow \mathrm{H}_{2} \mathrm{SO}_{4}\right)$ and biotic (microbially-assisted) with different kinetics. In order to evaluate the biotic or abiotic sulfide consumption, two experiments were carried out. In the experiment, the spring water samples, and for comparison, a standard sulfide solutions were monitored at a different time. Aliquots of $40 \mathrm{ml}$ of standard sodium sulfide and spring water samples (both not stabilized) were stored in falcon tubes for 30 days, nearby the sulfidic spring, at the same temperature and darkness conditions. Additional aliquots of spring water and standard sodium sulfide were stabilized with zincum acetate after the sampling, as reference at time zero. The standard sodium sulfide solution concentration was $18.5 \mathrm{ppm}$, within the sulfide concentrations range for the sulfidic-spring water.

In the second experiment (September 2013) a detailed kinetic study was performed to evaluate the sulfide consumption at different times. In particular eight spring water aliquotes were sampled and zinc acetate was added, respectively, after 2, 4, 8, 16, 24, 32 , and 44 hours.

\section{RESULTS AND DISCUSSION}

Monte Conca Cave is the first reported example of karst system developed in gypsum, that contains an active sulfidic spring accompanied by a rich microbiota. The characterization of the sulfidic-spring and its peculiar morphologies, as snottites and sulfur suspensions, indicate the presence of sulfur bacteria, which might represent the food source for a chemo-autotrophically based ecosystem. The fauna monitoring in the cave has shown the presence of more than 50 invertebrate species, belonging to different phyla. The most part of them are trogloxene species, which are present in function of the water flow in the cave. The observations seem to suggest that many trogloxene species are able to survive within the cave and in some cases to reproduce underground, due to the abundance of trophic resources. Some of the observed species show typical troglophile or troglobite characteristics, such as depigmentation and anophthalmia. The greatest abundance of taxa was found in the sulfidic spring area and it suggests a complex food web associated with it. Here, as stygobiont species, particularly abundant are Haplotaxida (Anellida), Hydrobiidae (Gasteropoda) and Proasellus sp. (Isopoda, Asellidae). These species are prey for Nepa cinerea (Hemiptera, Nepidae) and at least three species of Agabus (Coleoptera, Dytiscidae), trogloxene species that are able to survive in the sulfidic water. Among the rotting plant detritus material near the spring, we observed detritivore troglophile or troglobite species, such as Mastigonodesmus destefani (Diplopoda, Polydesmida), Haplophthalmus danicus (Isopoda, Trichoniscidae) and Folsomia candida (Collembola, Isotomidae). Currently we are working on a new paper focused on the fauna of Monte Conca Cave. Table 3 and Fig. 8 report some examples of the fauna identified in the cave.

\section{Air and water temperature}

The air temperature in the sulfidic spring area (zone is displayed by a red dash circle in Figs. 1 and 2) was at least $1^{\circ} \mathrm{C}$ higher than the average temperature of the cave, up to the highest value of $2.1^{\circ} \mathrm{C}$ recorded in January 2013 (Table 1). The mean value of air temperature in the cave was $15.6^{\circ} \mathrm{C}$, with a seasonal trend in agreement to the outside air temperature measured by SIAS (Servizio Informativo Agrometereologico Siciliano). The correlation between cave and outside temperature was also described in literature for other caves (Sarbu et al., 2000; Galdenzi et al., 2008). Indeed the mean value of air temperature measured in the sulfide spring zone was $16.9^{\circ} \mathrm{C}$, with a minimum of $16.4^{\circ} \mathrm{C}$ in January 2013 and a maximum of $17.6^{\circ} \mathrm{C}$ in July 2012. 
Table 3. Preliminary list of taxa observed nearby the sulfidic spring.

\begin{tabular}{|l|l|l|l|l|}
\hline \multicolumn{1}{|c|}{ Phylum } & \multicolumn{1}{c|}{ Class } & \multicolumn{1}{c|}{ Order } & \multicolumn{1}{c|}{ Family } & \multicolumn{1}{c|}{ Species } \\
\hline Anellida & Oligochaeta & Haplotaxida & Tubificidae & nd \\
\hline Artropoda & Entognatha & Collembola & Isotomidae & Folsomia candida Willem 1902 \\
\hline Artropoda & Insecta & Coleoptera & Dytiscidae & Agabus biguttatus (Olivier, 1795) \\
\hline Artropoda & Insecta & Coleoptera & Dytiscidae & Agabus bipustulatus (Linnaeus, 1767) \\
\hline Artropoda & Insecta & Coleoptera & Dytiscidae & Agabus brunneus Fabricius, 1768. \\
\hline Artropoda & Insecta & Hemiptera & Nepidae & Nepa cinerea Linnaeus, 1758 \\
\hline Artropoda & Diplopoda & Polydesmida & Polydesmidae & Mastigonodesmus destefani Silvestri, 1898 \\
\hline Artropoda & Aracnida & Araneae & Nesticidae & Nesticus eremita Simon 1879 \\
\hline Artropoda & Malacostraca & Isopoda & Asellidae & Proasellus sp. \\
\hline Artropoda & Malacostraca & Isopoda & Trichoniscidae & Haplophthalmus danicus (Budde-Lund, 1880) \\
\hline
\end{tabular}
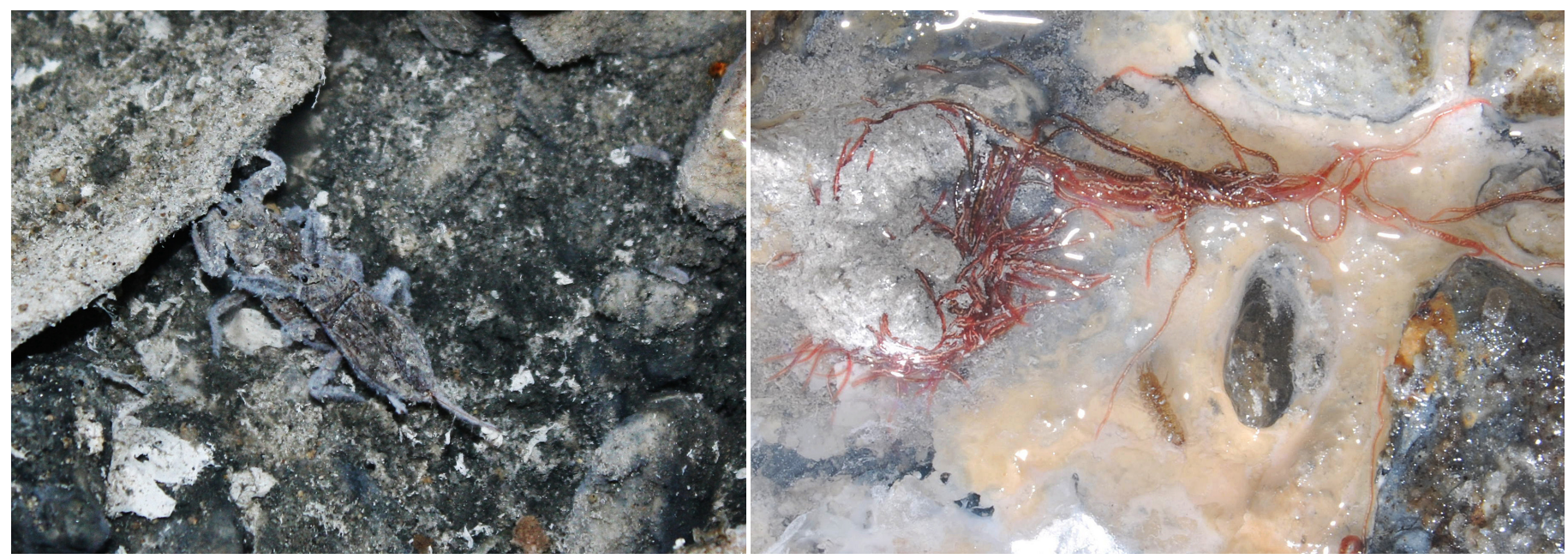

Fig. 8. left) Nepa cinerea (photo by P. Valenti); right) Oligochaeta Haplotaxida and Proasellus sp. in sulfidic water (photo by F. Fiorenza).

The sulfidic spring with an air temperature variation of just $0.5^{\circ} \mathrm{C}$ could be considered as an ecosystem able to counteract the external air temperature variation, more efficiently than the entire cave system which has shown a temperature variation of $1.3^{\circ} \mathrm{C}$. The relative humidity was about $90 \%$ throughout the cave.

Water temperature measurements showed that the spring water was always warmer than the cave water by about $2^{\circ} \mathrm{C}$. It is in agreement with the temperature data reported for the main sulfidic caves, except for the Acquasanta Terme Cave (Jones et al., 2010).

The cave water temperature decreased significantly in January 2013 as consequence of a large volume of cold water (outside air temperature $7.7^{\circ} \mathrm{C}$ ) that entered from the surface stream, while the spring water maintained a higher temperature. In May 2013, probably due to the very large volume of warm water that entered the cave $\left(425 \mathrm{~mm}\right.$ of rain at $19^{\circ} \mathrm{C}$ ), the smallest gap between the temperatures of the spring water and the water cave was observed. Cave water temperature increased up to the highest value of $15.3^{\circ} \mathrm{C}$ while the spring water still maintained its typical temperature of $16^{\circ} \mathrm{C}$. Figure 9 describes the temperatures trend for cave and spring water and for outside air temperature as a function of the millimeters of rain during the monitoring period.

The spring area has always shown air and water temperature higher than the air and water cave temperature. Herbet et al. (2005) describe a water temperature increase coincident with the microbial layer in the South Andrea Black Hole and Galdenzi et al. (2008) describe sulfidic ground water in the
Frasassi Cave slightly warmer than the seepage water. These features may be related to the bacterial life cycle. Indeed, according to Lehninger et al. (1993), living organisms can be considered as open thermodynamic systems that preserve their internal order by taking from their surroundings free energy as nutrients or sunlight and returning to the same surroundings an equal amount of energy as heat, compensating the order created within cells $\left(\Delta \mathrm{S}_{\text {system }}<0\right)$ with the disorder created in their surrounds $\left(\Delta \mathbf{S}_{\text {surroundings }}>0\right)$.

In this way the total entropy still remain positive: $\Delta \mathrm{S}_{\text {total }}=\Delta \mathrm{S}_{\text {system }}+\Delta \mathrm{S}_{\text {surroundings }}>0$.

Meantime, many chemical reactions at the basis of biological processes occur with negative enthalpy that means releasing of heat in the surround and, consequentially, surrounding temperature increase. Negative value of enthalpy and positive value of entropy contribute to the decrease of the Gibbs free energy of the system, as described by the Gibbs free energy equation: $\Delta \mathrm{G}=\Delta \mathrm{H}-\mathrm{T} \Delta \mathrm{S}<0$.

\section{pH measurements}

During the wet season (January-May 2013), the $\mathrm{pH}$ values for cave and spring water were quite similar with an average value of about 7.5 , probably due to the large volume of stream water that flowed into the cave, diluting the spring water (Table 1).

The $\mathrm{pH}$ recorded in the dry season (June-September 2012 and June-September 2013) for the cave water was about 7.5, while for spring water was about 6.8 (Table 1). As well as due to the $\mathrm{H}_{2} \mathrm{~S}$ content, the $\mathrm{pH}$ 


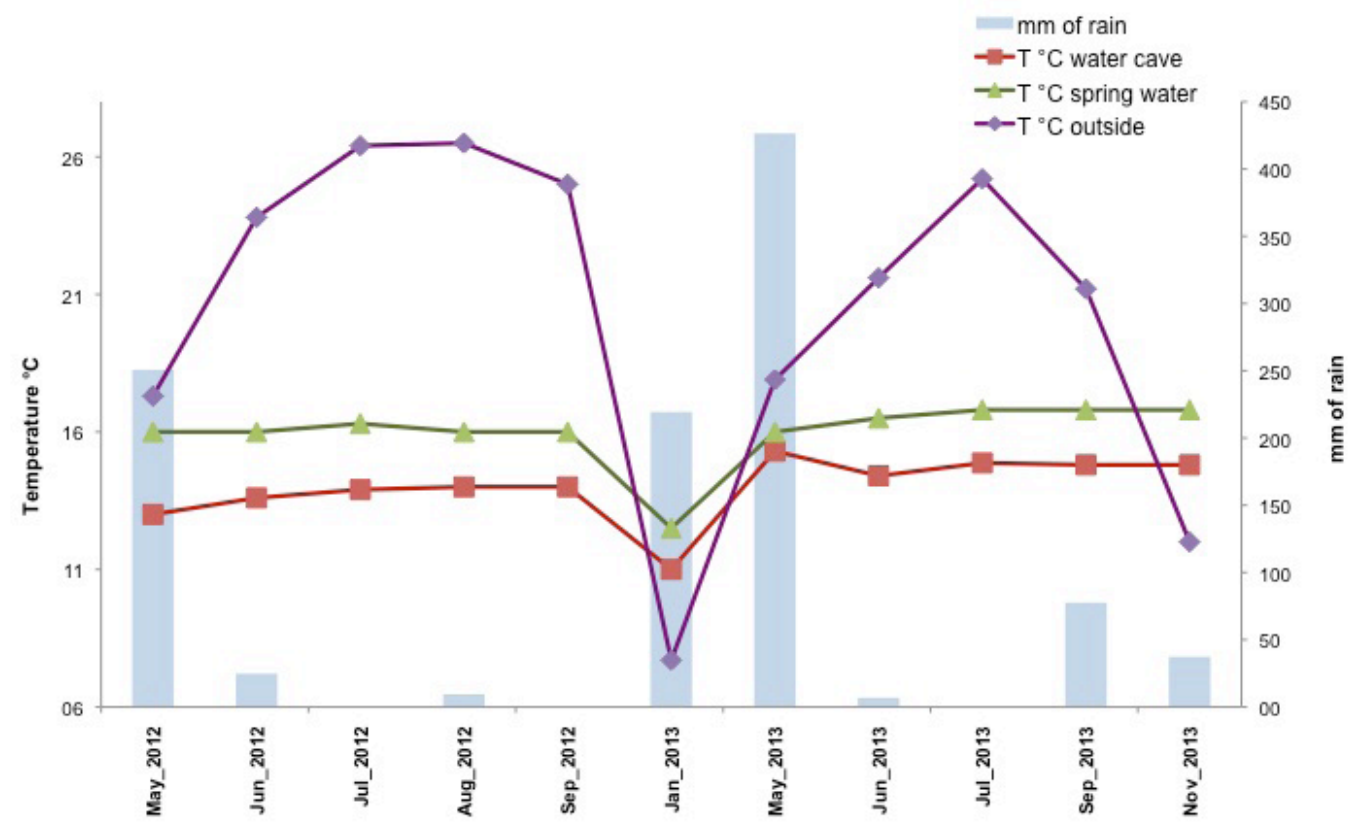

Fig. 9. The plot of water spring, cave, and surface temperatures versus the amount of rain $(\mathrm{mm})$, during the monitored period.

decrease found for spring water might be related to microbial activity. It is well know that different Beggiatoa species are predominantly distributed in the suboxic and oxic zone, in which $\mathrm{O}_{2}$ is used as the electron acceptor for the oxidation of $\mathrm{H}_{2} \mathrm{~S}$ to $\mathrm{S}^{0}$ in a first step and to $\mathrm{SO}_{4}{ }^{2-}$ in a second one (Sayama et al., 2005; Kamp et al., 2006; Preisler et al., 2007). One of the hydrolytic species at the $\mathrm{pH}$ value measured is $\mathrm{HS}^{-}$, so the biological aerobic oxidation could be summarized by the following reactions:

$$
\begin{gathered}
2 \mathrm{HS}^{-}+\mathrm{O}_{2}+2 \mathrm{H}^{+} \rightarrow 2 \mathrm{~S}^{0}+2 \mathrm{H}_{2} \mathrm{O} \\
2 \mathrm{~S}^{0}+3 \mathrm{O}_{2}+2 \mathrm{H}_{2} \mathrm{O} \rightarrow 2 \mathrm{SO}_{4}^{2-}+4 \mathrm{H}^{+}
\end{gathered}
$$

The second oxidation step is an acidogenic process that produces sulfuric acid, which contributes to the $\mathrm{pH}$ decrease and the increase of sulfate amount in spring water, according to our results.

\section{$\mathrm{H}_{2} \mathrm{~S}$ measurements}

The peculiar feature to demonstrate the sulfidic nature of a spring water is the presence of $\mathrm{H}_{2} \mathrm{~S}$ amount at concentration higher than $1 \mathrm{ppm}$. The spring water of Monte Conca is well known to the cavers for the bad smell of rotten eggs that suggests the presence of sulfidric acid. Our monitoring, for the first time, highlighted the high sulfide content in the spring water of the lower gallery. The data reported in Table 1 indicates, a negligible $\mathrm{H}_{2} \mathrm{~S}$ amount, ranging from $0.03 \mathrm{ppm}$ to $0.18 \mathrm{ppm}$ in the cave water; while for the spring water a $\mathrm{H}_{2} \mathrm{~S}$ amount one and two order of magnitude higher was found. Although the $\mathrm{H}_{2} \mathrm{~S}$ level in spring water was always higher than cave water, its values were strictly dependent on the seasons. Changes in sulfide concentration, correlated with the relative dilution of groundwater and caused by the amount of seepage water during the wet seasons, was also described by Galdenzi et al. (2008) for Frasassi Cave.

Noteworthy was the gradient of sulfide concentrations monitored in the spring water at three different depth levels, water surface, depths of 15 and $30 \mathrm{~cm}$. The results are shown in Fig. 10. The data indicate a lower sulfide concentration for the first level and similar values for the other two levels, always higher than the first one. This difference is in agreement to the presence of clearly visible microbial mats at the surface and in the shallow water, that consume the sulfide for their metabolism.

Table 1 reports only the mean values of $\mathrm{H}_{2} \mathrm{~S}$ content for the three depth levels. The $\mathrm{H}_{2} \mathrm{~S}$ concentration values were obtained by water samples stabilized with zinc acetate because the same samples unstabilized have shown a negligible $\mathrm{H}_{2} \mathrm{~S}$ amount. All sulfide quantitative measurements were carried out in laboratory, 20 hours after sampling. The evident presence of filamentous microbial mats in sulfide spring water and the fast sulfide consumption suggests that the microbial mats could be composed of sulfur oxidant bacteria, such as Beggiatoa and Acidithiobacillus.

\section{$\mathrm{H}_{2}$ S consumption rate}

In order to evaluate the biotic $\mathrm{H}_{2} \mathrm{~S}$ consumption in spring water samples a kinetic comparison with a pure abiotic consumption in aqueous sodium sulfide solution was performed. The experimental results for not stabilized aliquots of spring water samples (stored for 30 days) have reported the complete disappearance of sulfide, whereas no significant change occurred for the sodium sulfide samples (Table 4). These experiments were replicated at two different times. Our results are in agreement with the literature data which reports that abiotic oxidation rates are generally very slow (Millero et al., 1987). Recently, Luther et al. (2013) report an abiotic sulfide consumption rate of about $1 \mu \mathrm{M}$ per day despite a biotic rate of about one thousand time higher was recently reported.

Based on our experimental evidences and literature data we have performed detailed kinetic studies to evaluate the sulfide consumption at different time periods. In particular, in September 2013 have been sampled 8 spring water aliquotes. In the first one 
zinc acetate was added immediately, in the seven remains aliquots zincum acetate was added after 2, 4, $8,16,24,32$, and 44 hours respectively. The results indicate a drastic decrease of sulfide concentration after just two hours (Fig. 11) according to the high sulfide consumption rate typically for biotic oxidation.

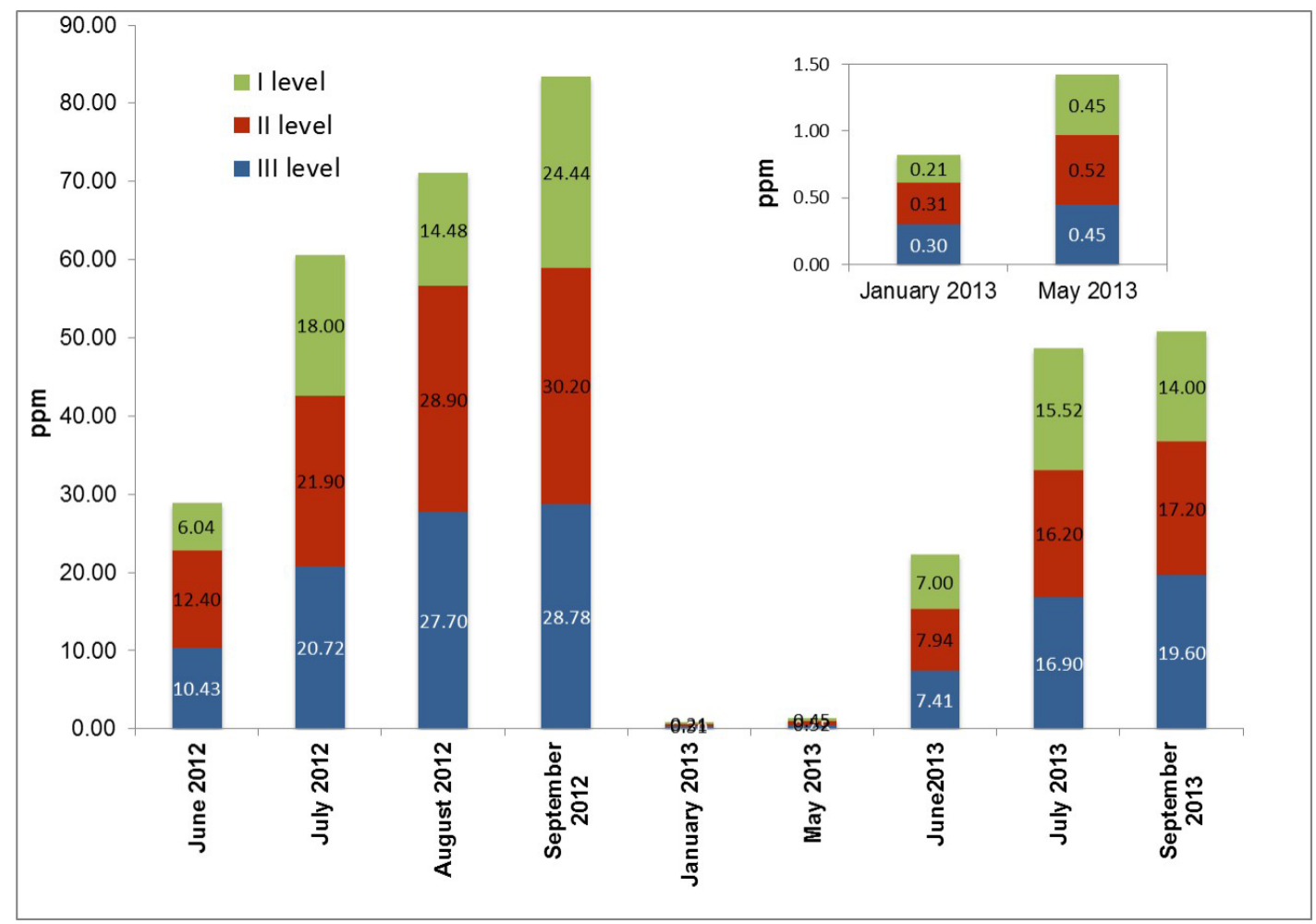

Fig. 10. Sulfide concentrations (ppm) for the three different levels monitored in sulfidic spring. In inset, the data for January and May 2013.

Table 4. Sulfur amount for stabilized and unstabilized samples at different storage times.

\begin{tabular}{|c|c|c|c|c|c|}
\hline & & \multicolumn{2}{|c|}{ Spring water } & \multicolumn{2}{|c|}{ Aqueous sulfide solution $\left(\mathrm{Na}_{2} \mathbf{S}\right)$} \\
\hline & & $\begin{array}{c}\text { Stabilized sample } \\
\text { (with } \mathrm{Zn} \text {-acetate) }\end{array}$ & $\begin{array}{l}\text { Not stabilized } \\
\text { sample }\end{array}$ & $\begin{array}{l}\text { Stabilized sample } \\
\text { (with Zn-acetate) }\end{array}$ & $\begin{array}{c}\text { Not stabilized } \\
\text { sample }\end{array}$ \\
\hline \multirow{2}{*}{ July 2012} & Time zero * & 27.8 & 0.20 & 18.5 & 18.5 \\
\hline & 30 days & 27.6 & 0.16 & 18.4 & 18.3 \\
\hline \multirow{2}{*}{ July 2013} & Time zero * & 16.2 & 0.15 & 18.5 & 18.5 \\
\hline & 30 days & 16.1 & 0.14 & 18.5 & 18.1 \\
\hline
\end{tabular}

* samples analyzed in laboratory after 20 hrs

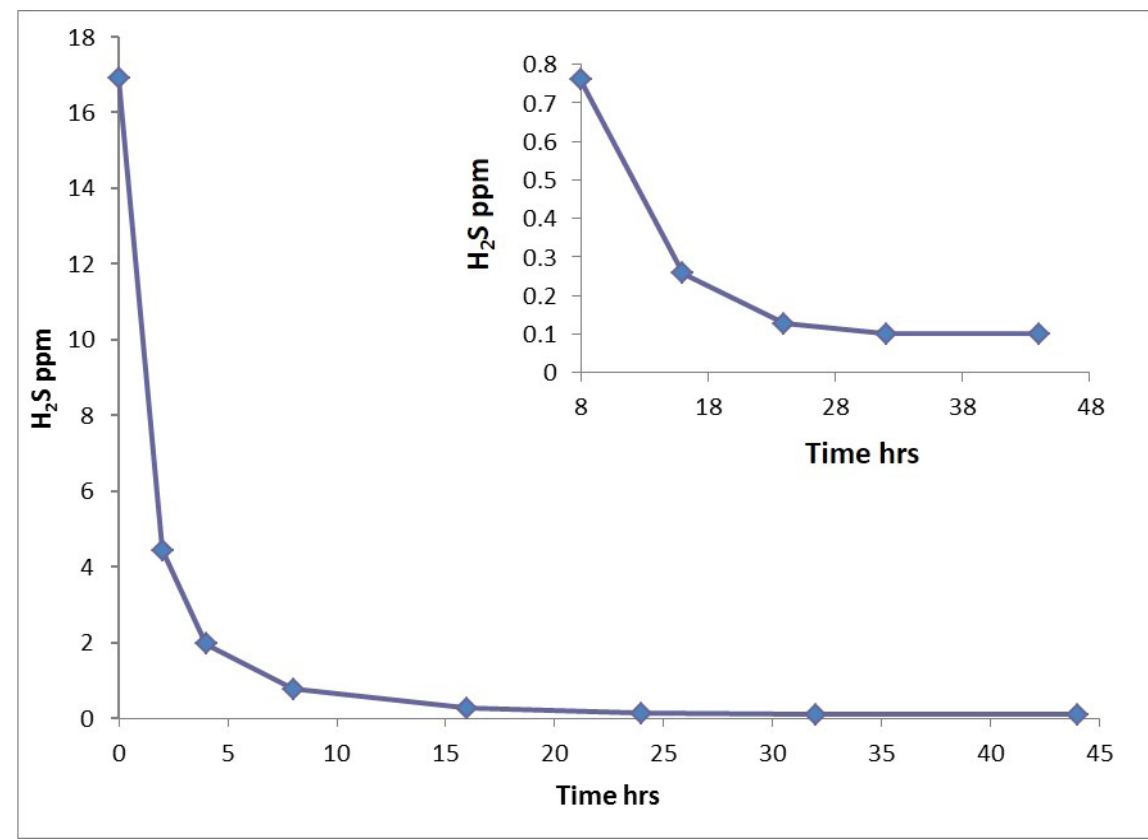

Fig. 11. Sulfur consumption for unstabilized spring water sample at different storage times. Inset the detailed kinetic after $8 \mathrm{hrs}$ storage time.

\section{Water chemistry: nitrate measurements by MS}

As reported in Table 2 the cave and spring water showed different ion composition and chemical-physical parameters. The data have confirmed the abundance of sulfate in the spring water and the total sulfide consumption (for not stabilized samples). The different nitrate amount between the two waters, respectively 3 and $<0.1 \mu \mathrm{M}$, might be a further evidence of thiobacterial activity. Low nitrate concentrations were found in sulfidic spring of Acquasanta Terme Cave and in Frasassi Cave, respectively $<1 \mu \mathrm{M}$ and $<0.7 \mu \mathrm{M}$, suggesting that nitrate is scavenged by anaerobic microorganisms (Macalady et al., 2006; Jones et al., 2010). Indeed, as widely reported in literature, different Beggiatoa species employ nitrate in their metabolism, 
especially, in the anoxic water zones (Mußmann et al., 2003; Kamp et al., 2006; Engel, 2007; Hinck et al., 2007; Preisler et al., 2007; Yekta, 2011). These Beggiatoa species contain nitrate reductase which enables them to use nitrate as electron acceptor to sulfide oxidation (MacHatton at al., 1996). They are able to internally accumulate nitrate in levels up to some order of magnitude higher than the nitrate concentration of their surrounding water (Kamp et al., 2006) using this intracellular stored nitrate for sulfide oxidation with spatially separated pathways. As proposed by Sayama et al. (2005) the Beggiatoa filaments stored nitrate in vacuoles and transport it downwards to anoxic zone, with their gliding mechanism. This stored nitrate is used for anaerobic sulfide oxidation to elemental sulfur, which will be stored in vacuoles for aerobic oxidation to sulfate in oxic zone. In Beggiatoa cultures the nitrate amount decrease from the initial amount, with a consequently nitrate enrichment on bacteria vacuoles (Kamp et al., 2006).

$$
\begin{aligned}
& \left(\mathrm{NO}_{3}{ }^{-}\right)_{\text {dissolved }} \rightarrow\left(\mathrm{NO}_{3}^{-}\right)_{\text {intracellular }} \\
& 4 \mathrm{HS}^{-}+\left(\mathrm{NO}_{3}^{-}\right)_{\text {intracellular }}+6 \mathrm{H}^{+} \rightarrow 4\left(\mathrm{~S}^{0}\right)_{\text {intracellular }}+ \\
& +\mathrm{NH}_{4}^{+}+3 \mathrm{H}_{2} \mathrm{O} \\
& 2\left(\mathrm{~S}^{0}\right)_{\text {intracellular }}+3 \mathrm{O}_{2}+2 \mathrm{H}_{2} \mathrm{O} \rightarrow 2 \mathrm{SO}_{4}{ }^{2-}+4 \mathrm{H}^{+}
\end{aligned}
$$

\section{2-15e-3}

NITFREZ_BIS 1 (0.518) Sm (SG, 1 $\times 0.10)$

100

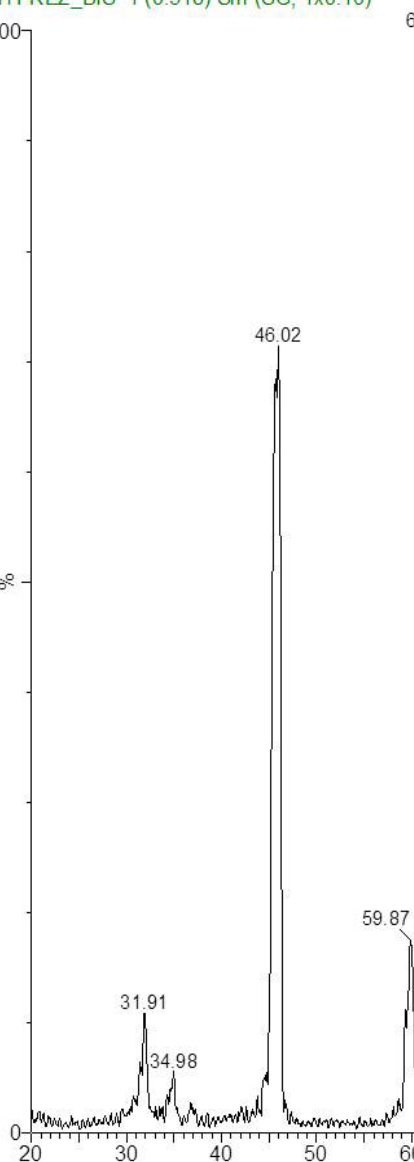

Considering the different nitrate amounts found into the two water samples (Table 2) and supported by literature data, additional experiments were performed to evaluate the presence of nitrate in filamentous mats of Monte Conca Cave. For this purpose triplicate samples of the microbial mats were analyzed using the method described by Hinck et al. (2007) and Preisler et al. (2007) revised by us. The samples were transferred into $250 \mu$ of deionized water and frozen at $-20^{\circ} \mathrm{C}$ for 2 days, causing cell rupture. After thawing, the samples were centrifuged ( 5 minutes at $4000 \mathrm{x}$ ) and the supernatants were analyzed in electrospray mass spectrometry (ESI-MS) in negative ion mode to search nitrate. The obtained results (Fig. 12) show the characteristic mass peaks for nitrate $(62.01 \mathrm{~m} / \mathrm{z}$, base peak) and for nitrite $(46.02 \mathrm{~m} / \mathrm{z})$. The found nitrate amounts were determined within the mats of the Monte Conca Cave and include the porewater nitrate as well as intracellular nitrate, released from the bacterial filaments (as described for Beggiatoa) during freezing and thawing. Therefore, in order to evaluate nitrate presence in spring water using mass spectrometry, an ESI spectrum of spring water sample, after filtering, was recorded at the same instrumental conditions. In this case the most abundant peaks refer to sulfate anion (Campana \& Risby, 1980) and nitrate peak is present under $10 \%$ of base peak.

Fig. 12. Mass spectra analysis of filamentous mats with the characteristic peaks for nitrate $(62.01 \mathrm{~m} / \mathrm{z})$ and nitrite (46.02 $\mathrm{m} / \mathrm{z})$.

\section{Water chemistry: sulfur measurements by MS}

Elemental sulfur content is closely related to bacterial activity because it is widely described that metabolism of various sulfur bacteria produce elemental sulfur as intermediate of the sulfide oxidation (Hose et al.,
2000; Barton \& Northup, 2005; Kamp et al., 2006; Engel, 2007; Hinck et al., 2007; Schwedt et al., 2012). In order to evaluate the elemental sulfur in microbial mats (reaction 4), the remaining pellet (after centrifugation) was dried in air and dissolved in $500 \mu \mathrm{l}$ 
of pure methanol for 3 days, therefore few $\mu 1$ of $0.1 \mathrm{M}$ $\mathrm{NaOH}$ solution were added up to $\mathrm{pH} 10$. After 4 hours, the sample was centrifuged ( 5 minutes at $4000 \mathrm{x}$ ) and the supernatant was analyzed by ESI-MS in negative ion mode in order to evaluate polysulfide signals. At basic $\mathrm{pH}$, the disproportionation of polysulfide is induced (equation 6), thus analytical species can be analyzed in ESI-MS (Gun et al., 2004).

$$
4 \mathrm{~S}_{(\mathrm{n})}{ }^{0}+6 \mathrm{OH}^{-} \rightarrow \mathrm{S}_{2} \mathrm{O}_{3}{ }^{2-}+2 \mathrm{~S}^{2-}+3 \mathrm{H}_{2} \mathrm{O}
$$

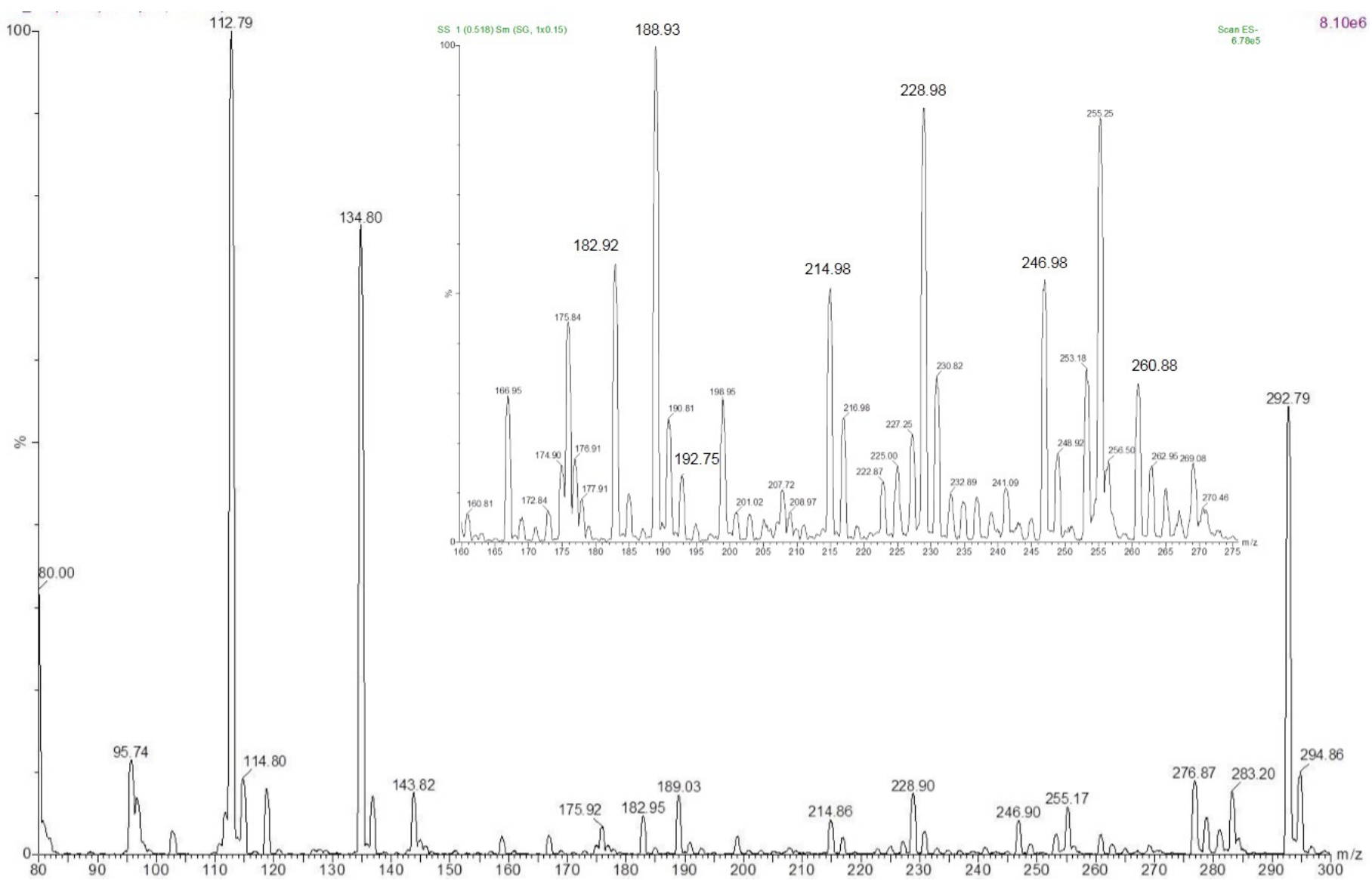

Fig. 13. Microbial mat mass spectra for sulfur, which show peaks for thiosulfate poly-sulfides chains peaks (see table 5 for the assignment of peaks).

Table 5. Characteristic mass peaks for sulfidic spring water, snottites. and filamentous microbial mats treated for nitrate or sulfur.

\begin{tabular}{|c|c|c|c|c|c|c|c|c|c|c|}
\hline \multirow{2}{*}{$\begin{array}{c}\text { Samples } \\
\begin{array}{c}\text { Sulfidic spring } \\
\text { water }\end{array}\end{array}$} & \multicolumn{10}{|c|}{ Species (m/z) } \\
\hline & $\begin{array}{c}\mathrm{Cl}^{-} \\
(34.58)\end{array}$ & $\begin{array}{c}\mathrm{NO}_{2}^{-} \\
(45.67)\end{array}$ & $\begin{array}{c}\mathrm{SO}_{3}^{-} \\
(79.79)\end{array}$ & $\begin{array}{l}\mathrm{HSO}_{4}^{-} \\
(96.70)\end{array}$ & & & & & & \\
\hline $\begin{array}{c}\text { Microbial mat } \\
\text { (Nitrate/Nitrite } \\
\text { species) }\end{array}$ & $\begin{array}{c}\mathrm{NO}_{2}^{-} \\
(46.02)\end{array}$ & $\begin{array}{c}\mathrm{NO}_{3}^{-} \\
(62.01)\end{array}$ & & & & & & & & \\
\hline $\begin{array}{l}\text { Microbial mat } \\
\text { (Sulfur species) }\end{array}$ & $\begin{array}{c}\mathrm{HS}_{2} \mathrm{O}_{3}^{-} \\
(112.79)\end{array}$ & $\begin{array}{l}\mathrm{NaS}_{2} \mathrm{O}_{3}^{-} \\
(134.80)\end{array}$ & $\begin{array}{c}\mathrm{Na} \mathrm{S}_{5}^{-} \\
(182.92)\end{array}$ & $\begin{array}{c}\mathrm{HS}^{-} \\
2 \mathrm{Na}_{2} \mathrm{~S} \\
(188.93)\end{array}$ & $\begin{array}{c}\mathrm{HS}_{6}^{-} \\
(192.75)\end{array}$ & $\begin{array}{c}\mathrm{NaS}_{6}^{-} \\
(214.98)\end{array}$ & $\begin{array}{c}\mathrm{NaS}_{4}^{-} \\
\mathrm{Na}_{2} \mathrm{~S} \\
(228.98)\end{array}$ & $\begin{array}{c}\mathrm{NaS}_{7}^{-} \\
(246.98)\end{array}$ & $\begin{array}{c}\mathrm{NaS}_{5}{ }^{-} \\
\mathrm{Na}_{2} \mathrm{~S} \\
(260.88)\end{array}$ & $\begin{array}{l}\mathrm{NaS}_{2} \mathrm{O}_{3}^{-} \\
\mathrm{Na}_{2} \mathrm{~S}_{2} \mathrm{O}_{3} \\
(292.79)\end{array}$ \\
\hline Snottites & $\begin{array}{c}\mathrm{SO}_{3}^{-} \\
(79.81)\end{array}$ & $\begin{array}{l}\mathrm{HSO}_{4}^{-} \\
(96.99)\end{array}$ & & & & & & & & \\
\hline
\end{tabular}

All these data have demonstrated that the microbial mats contain species that are able to perform anaerobic sulfide oxidation (reaction 4). The metabolism of these microbial species could use the sulfide as main electron donor to produce intermediate species of sulfur (Engel, 2007; Hinck et al., 2007; Berg et al., 2013) and, as Engel (2007) describes, the elemental sulfur would be produced intra or extracellular. Therefore, elemental sulfur could be found as solid suspensions giving a milky color to the water surface
Figure 13 reports the mass spectra that show the characteristic peaks for thiosulfate and polysulfides chains (inserted spectrum from 160 to $275 \mathrm{~m} / \mathrm{z}$ ). Significant changes in signal enhancement were recorded by varying the cone voltage from 30 to $80 \mathrm{~V}$ and the spray voltage from 2.5 to $4.5 \mathrm{kV}$, so, in order to enhance the linear polysulfide peaks respect to the polysulfide adducts, compromise values of $35 \mathrm{~V}$ and $3.5 \mathrm{kV}$ were respectively chosen. Table 5 reports the main assigned peaks. 
(Hose et al., 2000; He et al., 2005; Hose \& Macalady, 2006; Baskar et al., 2008; Jones et al., 2011; Dopson \& Johnson, 2012), Beggiatoa (Nelson et al., 1986; Hose \& Macalady, 2006; Preisler et al., 2007; Druschel et al, 2008) or other sulfur bacteria, can oxidize hydrogen sulfide to sulfuric acid, using Fe(III) as electron acceptor for the sulfide anaerobic oxidation. Oxidized iron is reduced by $\mathrm{HS}^{-}$as described in reaction 7 .

$$
2 \mathrm{FeOOH}+\mathrm{HS}^{-}+5 \mathrm{H}^{+} \rightarrow 2 \mathrm{Fe}^{2+}+\mathrm{S}^{0}+4 \mathrm{H}_{2} \mathrm{O}
$$

Meantime, the soluble reduced iron reacts with HS to form insoluble iron sulfide.

$$
\mathrm{Fe}^{2+}+\mathrm{HS}^{-} \rightarrow \mathrm{FeS}_{\downarrow}+\mathrm{H}^{+}
$$

Black deposits of iron sulfide were largely found in water spring of Monte Conca. The thiocyanate assay, performed on these deposits, has disclosed the presence of iron. A portion of black deposit was dissolved in chloridic acid and oxidized to $\mathrm{Fe}^{3+}$ as reported in reactions 9-10. In presence of NaSCN, the $\mathrm{Fe}^{3+}$ forms a characteristic bloody red compound of $\mathrm{FeSCN}^{2+}$ (reaction 11) with the typical absorbance at $460 \mathrm{~nm}$ (Fig. 14). In Fig. 14 for comparison is reported the absorption UV-Vis spectrum of a $\mathrm{FeSCN}^{2+}$ reference solution $\left(2 \times 10^{-5} \mathrm{M}\right)$. The same thiocianate assay performed into a spring water sample has given a negative result according to the complete disappearance of $\mathrm{Fe}^{2+}$ from solution, due to its complete precipitation as FeS.

$$
\begin{gathered}
\mathrm{FeS}+2 \mathrm{HCl} \rightarrow \mathrm{Fe}^{2+}+\mathrm{H}_{2} \mathrm{~S}+2 \mathrm{Cl}^{-} \\
4 \mathrm{Fe}^{2+}+\mathrm{O}_{2}+4 \mathrm{H}^{+} \rightarrow 4 \mathrm{Fe}^{3+}+2 \mathrm{H}_{2} \mathrm{O} \\
\mathrm{Fe}^{3+}+\mathrm{NaSCN} \rightarrow \mathrm{Fe}(\mathrm{SCN})^{2+}+\mathrm{Na}^{+}
\end{gathered}
$$

\section{Snottites}

The presence of abundant snottites (Fig. 6), described for the first time in a gypsum cave, indicates the existence of a large aerial microbial life related to the

sulfide-rich water microbial life (Fig. 7). As described in literature (Hose \& Macalady, 2006; Jones et al., 2011; Dopson \& Johnson, 2012) snottites have very low biodiversity and are dominated by Acidithiobacillus thiooxidans. Actinobacteria related to Acidimicrobium ferrooxidans have also been detected in Frasassi snottites. This suggests the importance of the iron ions in the bacterial activity development.

In order to investigate the presence of iron in the snottites of Monte Conca Cave, a sample was analyzed with thiocianate assay, giving a positive result (Fig. 14). Furthermore sulfate and $\mathrm{pH}$ measurements on secreting acid drop were performed. The $\mathrm{pH}$ measured in situ by $\mathrm{pH}$ indicator strips (Fig. 7 right) and in laboratory by $\mathrm{pH}$-meter, has shown a $\mathrm{pH}$ value ranging from 0.5 to 1.0 unit. The sulfuric acid dropped by snottites was analysed by mass spectrometry (Fig. 15) and the results reported on Table 5 indicate the presence of pure sulfuric acid.

As noted by Hose et al. (2000), Acidithiobacillus thiooxidans in the most abundantly species in snottites. Under low oxygen content is capable of producing a local $\mathrm{pH}$ of about 2 , whereas in the presence of air, the $\mathrm{pH}$ may drop below 1 . Therefore, the $\mathrm{pH}$ values measured for the snottites sampled in Monte Conca, suggests totally aerobic condition for the sulfide oxidation. In addition, the same authors report a strongly exothermic process for the complete oxidation of hydrogen sulfide to sulfuric acid, mediated by sulphur-oxidizing bacteria. A negative enthalpy means heat release and simultaneous temperature increase of the surroundings. In our case, the strongly exothermic process involved in snottites genesis could contribute to the increase of the air temperature in the spring area. Moreover, the presence of sulfate in snottites was further confirmed by its precipitation as barium sulfate after addition of a barium chloride solution.

\section{CONCLUSIONS}

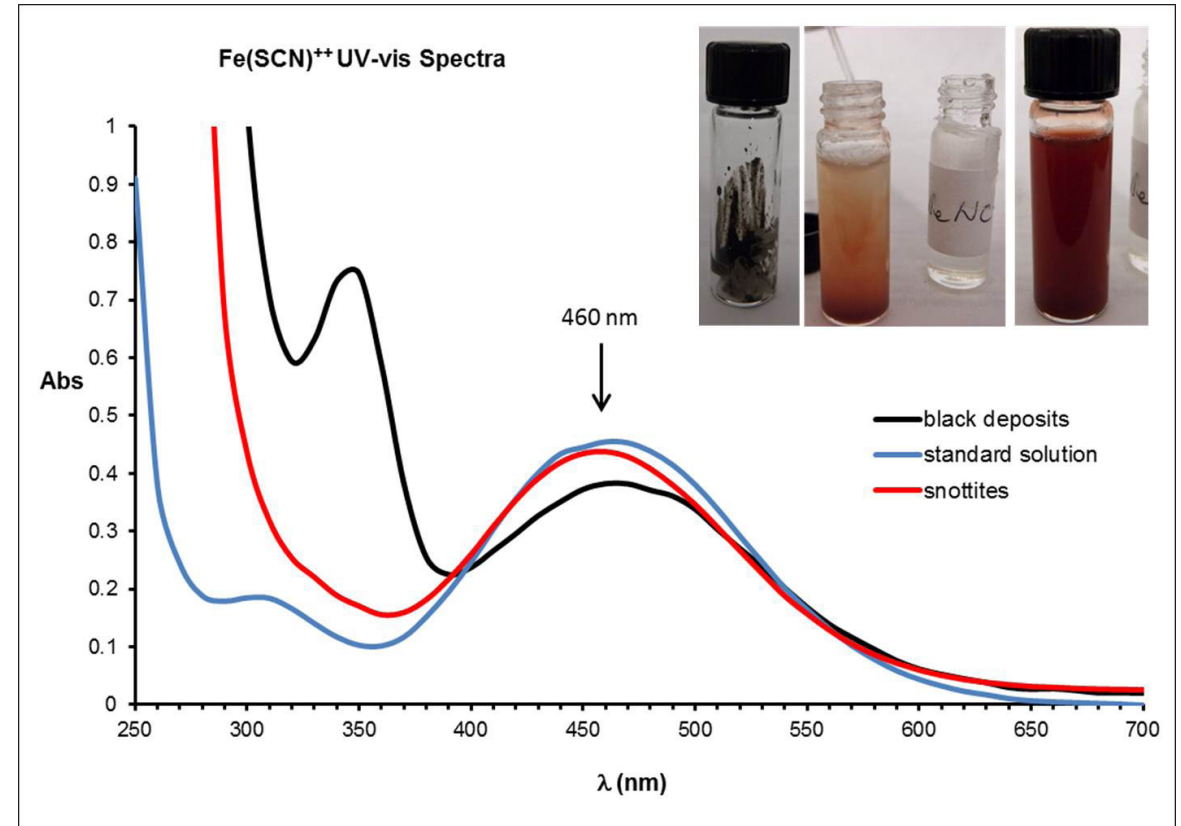

Fig. 14. UV-Vis spectra of $\mathrm{Fe}(\mathrm{SCN})^{2+}$ obtained from black deposit, snottites samples and $\mathrm{Fe}^{3+}$ acqueous solution as reference.
The aims of this work have been the monitoring of the main chemicalphysical parameters of the Monte Conca Cave and the identification and the characterization of its sulfidicspring, located in the terminal gallery. The evaluation of the main chemical features that are peculiar of sulfidicspring cave, indicates a clear evidence of bacterial activity.

The monitoring activity, conducted over 18 months, has shown the difference of chemical-physical parameters between the sulfidic spring and the rest of the cave, highlighting a microenvironment that is less influenced by external conditions.

The main features of a sulfidic spring, widely described in literature, were discovered in Monte Conca Cave. The evaluation of these features and the considering of additional evidences 


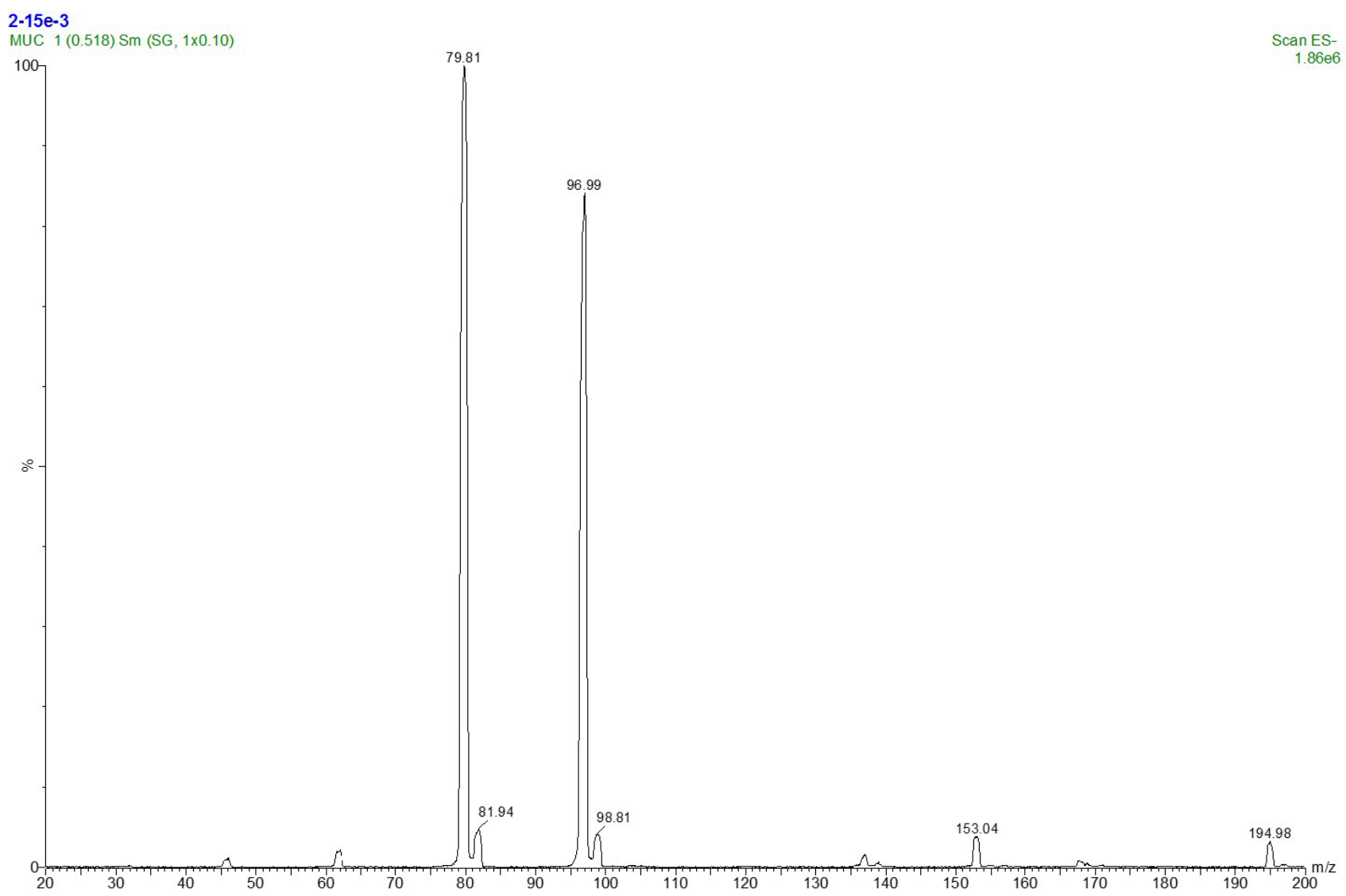

Fig. 15. Mass spectrum of sulfuric acid dripping from snottites (SO ${ }^{3-} 79.81 \mathrm{~m} / \mathrm{z}$ and $\mathrm{HSO}^{4-} 96.99 \mathrm{~m} / \mathrm{z}$ ).

such as biotic sulfide consumption, presence of nitrate on filamentous mats, and the different $\mathrm{pH}$ values between cave and spring water allowed to characterize, for the first time, a complex sulfidic system in a gypsum karst system.

Thus, Monte Conca Cave represents the only gypsum karst system described so far that includes an active sulfidic spring with an undoubtedly microbial activity. The presence of sulfur bacteria may be the source of an autotrophic system in close correlation with the biological cycle of many species of living organisms. Noteworthy is that in this study no biological measurements were carried out to ascertain the nature of the microbiota clearly present in the sulfidic spring, but only chemical and chemicalphysical measurements were carried out. The greater abundance of taxa found close to the sulfidic spring seems to suggest a complex food web associated with it and biological studies are needed for a complete site descriptions. At present, a detailed investigation of the fauna living in sulfidic-spring area is in progress and in addition, future investigation will focus on molecular biological methods to identify the microbial species.

\section{ACKNOWLEDGEMENTS}

We gratefully acknowledge Vincenzo Biancone, Director of Monta Conca Reserve who allowed the research activities. We thank the cavers of Centro Speleologico Etneo and Nisida for their contribution to the activities, and Dr. Bruno Catara, director of NCM service laboratory, for the Ion Chromatography measurements. A special thanks to Dr. Serban Sarbu who carefully reviewed this paper.

\section{REFERENCES}

Angert E.R., Northup D.E., Reysenbach A., Peek A.S., Goebel B.M. \& Pace N.R., 1998 - Molecular phylogenetic analysis of a bacterial community in Sulphur River, Parker Cave, Kentucky. American Mineralogist, 83: 1583-1592.

Barton H.A. \& Northup D.E., 2005 - Geomicrobiology in a cave environments: Past, current and future perspectives. Journal of Cave and Karst Studies, 69 (1): 163-178.

Baskar S., Baskar R., Lee N., Kaushik A. \& Theophilus P.K., 2008 - Precipitation of iron in microbial mats of the spring waters of Borra Caves, Vishakapatnam, India: some geomicrobiological aspects. Environmental Geolology, 56: 237-243. http://dx.doi.org/10.1007/s00254-007-1159-y

Berg S.J., Schwedt A., Kreutzmann A.C., Kuypers M.M.M. \& Milucka J., 2013 - Polysulfides as intermediates in the oxidation of sulfide to sulfate by Beggiatoa. Applied and Environmental Microbiology, 80 (2): 629-636. http://dx.doi.org/10.1128/AEM.02852-13

Cacchio P., Ercole C., Contento R., Cappuccio M., Preite Martinez M., Del Gallo M. \& Lepidi A., 2012 - Involvement of bacteria in the origin of a newly described speleothem in the gypsum cave of Grave Grubbo (Crotone, Italy). Journal of Cave and Karst Studies, 74 (1): 7-18.

http://dx.doi.org/10.4311/2010MB0136R

Campana J.E. \& Risby T.H., 1980 - Analysis of sulfuric acid aerosol by negative ion chemical ionization mass spectrometry. Analytical Chemistry, 52: 398-400. http://dx.doi.org/10.1021/ac50053a007

Cline J.D., 1969 - Spectrophotometric determination of hydrogen sulfide in natural waters. Limnology and Oceanography, 14 (3): 454-458. http://dx.doi.org/10.4319/10.1969.14.3.0454

Dopson M. \&Johnson D.B., 2012 - Biodiversity, metabolism and applications of acidophilic sulfur-metabolizing microorganisms. Environmental Microbiology, 14 (10): 2620-2631.

http://dx.doi.org/10.1111/j.1462-2920.2012.02749.x 
Druschel G.K., Emerson D., Sutka R., Suchecki P. \& Luther III G.W., 2008 - Low-oxygen and chemical kinetic constraints on the geochemical niche of neutrophilic iron(II) oxidizing microorganisms. Geochimica et Cosmochimica Acta, 72: 3358-3370.

http://dx.doi.org/10.1016/j.gca.2008.04.035

Dunker R., Røy H., Kamp A. \& Jørgensen B.B., 2011 - Motility patterns of filamentous sulfur bacteria, Beggiatoa spp. Federation of European Microbiological Societies - Microbiology Ecology, 77: 176-185.

Engel A.S., 2000 - Microbially-enhanced weathering in subsurface habitats: sulfur-oxidizing bacteria and the cave environment. Proceedings of the Friends of Karst Meeting, Cluj, Romania - B. Onac and T. Tamas (eds.) Karst Studies and Problems, 2000 and Beyond, 130-134.

Engel A.S., Porter L.M., Kinkle B.K. \& Kane T.C., 2001 - Ecological assessment and geological significance of microbial communities from Cesspool Cave, Virginia. Geomicrobiology Journal, 18: 259-274.

http://dx.doi.org/10.1080/01490450152467787

Engel A.S., Lee N., Porter L.M., Stern A.L., Bennett C.P. \& Wagner M., 2003 - Filamentous "Epsilonproteobacteria" dominate microbial nats from sulfidic cave springs. Applied and Enviromental Microbiology, 69 (9): 5503-5511. http://dx.doi.org/10.1128/AEM.69.9.5503-5511.2003

Engel A.S., Stern L.A. \& Bennett P.C., 2004 - Microbial contributions to cave formation: new insights into sulfuric acid speleogenesis. Geology, 32 (5): 369-372. http://dx.doi.org/10.1130/G20288.1

Engel A.S., 2007 - Observation on the Biodiversity of sulfidic karst habitats. Journal of Cave and Karst Studies, 69 (1): 187-206.

Galdenzi S., Forti P. \& Menichetti M., 1999 - L'acquifero sulfureo di Frasassi: aspetti idrogeologici e naturalistici. Atti “Conv. Naz. sull'inquinamento delle grotte e degli acquiferi carsici e possibili ricadute sulla collettività" Ponte di Brenta, PD 1998, Ed. Imprimitur: 181-193.

Galdenzi S., Menichetti M., Sarbu S. \& Rossi A., 1999 - Frasassi caves: a biogenic hypogean karst system? Proceedings European Conference Karst 99, Etudes de Géographie physique. CAGEP, Université de Provence, Suppl. XXVIII: 101-106.

Galdenzi S. \& Maruoka T., 2003 - Gypsum deposits in the Frasassi caves, central Italy. Journal of Cave and Karst Studies, 65 (2): 111-125.

Galdenzi S., Cocchioni M., Morichetti L., Amici V. \& Scuri S., 2008 - Sulfidic ground-water chemistry in the Frasassi Caves, Italy. Journal of Cave and Karst Studies, 70 (2): 94-107.

Gun J., Modestov A.D., Kamyshny Jr.A., Ryzkov D., Gitis V., Golfman A., Lev O., Hultsch V., Grishek T. \& Worch E., 2004 - Electrospray ionization mass spectrometric analysis of aqueous polysulfide solutions. Microchimica Acta, 146: 229-237.

http://dx.doi.org/10.1007/s00604-004-0179-5

He Z., Hu Y., Zhong H., Hu W. \& Xu J., 2005 - Preliminary proteomic analysis of Thiobacillus ferrooxidans growing on elemental sulphur and $\mathrm{Fe}^{2+}$ separately. Journal of Biochemistry and Molecular Biology, 38 (3): 307-313. http://dx.doi.org/10.5483/BMBRep.2005.38.3.307

Herbert R.A., Ranchou-Peyruse A., Duran R., Guyoneaud R. \& Schwabe S. 2005 - Characterization of purple sulfur bacteria from South Andros Black Hole cave system: highlights taxonomic problems for ecological studies among the genera Allochromatium and Thiocapsa. Enviromental Microbiology, 7 (8): 1260-1268.

http://dx.doi.org/10.1111/j.1462-2920.2005.00815.x
Hinck S., Neu T.R., Lavik G., Mussmann M., de Beer D. \& Jonkers H.M., 2007 - Physiological adaptation of nitratestoring Beggiatoa sp. to diel cycling in a phototrophic hypersaline mat. Applied and Environmental Microbiology, 73 (21): 7013-7022. http://dx.doi.org/10.1128/AEM.00548-07

Hose L.D. \& Pisarowicz J.A., 1999 - Cueva de Villa Luz, Tabasco, Mexico: reconaissance studies of an active sulfur spring cave. Journal of Cave and Karst Studies, 61 (1): 13-21.

Hose L.D., Palmer A.N., Palmer M.V., Northup D.E., Boston P.J. \& DuChene, H.R., 2000 - Microbiology and geochemistry in a hydrogen-sulfide-rich karst environment. Chemical Geology, 169: 399-423.

http://dx.doi.org/10.1016/S0009-2541(00)00217-5

Hose L.D. \& Macalady J.L., 2006 - Observations from active sulfidic karst systems: Is the present the key to understanding Guadalupe mountain speleogenesis? New Mexico Geological Society Guidebook, 57 th Field Conference, Caves and Karst of Southeastern New Mexico: 185-194.

Jones D.S., Lyon E.H. \& Macalady J.L., 2008 Geomicrobiology of biovermiculations from the Frasassi Cave System, Italy. Journal of Cave and Karst Studies, 70 (2): 78-93.

Jones D.S., Tobler D.J., Schaperdoth I., Mainiero M. \& Macalady J.L., 2010 - Community structure of subsurface biofilm in the sulfidic caves of Acquasanta Terme, Italy. Applied and Enviromental Microbiology, 76 (17): 5902-5910.

http://dx.doi.org/10.1128/AEM.00647-10

Jones D.S., Albrecht H.L., Dawson K.S., Schaperdoth I., Freeman K.H., Pi, Y., Pearson A. \& Macalady J.L., 2012 Community genomic analysis of an extremely acidophilic sulfur-oxidizing biofilm. ISME Journal, 6 (1): 158-170.

Kamp A., Stief P. \& Schulz-Vogt H.N., 2006 - Anaerobic sulfide oxidation with nitrate by a freshwater Beggiatoa enrichment culture. Applied Environmental Microbiology, 72 (7): 4755-4760. http://dx.doi.org/10.1128/AEM.00163-06

Lehninger A., Nelson D.L. \& Cox M.L., 1993 - Principles of Biochemistry, Worth Publishers Inc., U.S.

Luther III G.W., Findlay A.J., MacDonald D.J., Owings S.M., Hanson T.E., Beinart R.A. \& Girguis P.R., 2013 - Thermodynamics and kinetics of sulfide oxidation by oxigen: a look at inorganically controlled reactions and biologically mediated processes in the environment. Frontiers in Microbiology, 2: 1-9.

Macalady J.L., Lyon E.H., Koffmann B., Alberton L.K., Meyer K., Galdenzi S. \& Mariani S., 2006 Dominant microbial populations in limestone-corroding stream biofilm, Fasassi cave system, Italy. Applied Enviroemntal Microbiology, 72 (8): 5596-5609.

http://dx.doi.org/10.1128/AEM.00715-06

Macalady J.L., Jones D.S. \& Lyon E.H., 2007 - Extremely acidic, pendulous cave wall biofilms from the Frasassi cave system, Italy. Environmental Microbiology, 9 (6): 1402-1414.

http://dx.doi.org/10.1111/j.1462-2920.2007.01256.x

MacHatton S.C., Barry J.P., Jannasch H.W. \& Nelson D.C., 1996 - High nitrate concentrations in vacuolate, autotrophic marine Beggiatoa spp. Applied and Environmental Microbiology, 62: 954-958.

Madonia G. \& Vattano M., 2011 - New Knowledge on the Monte Conca gypsum karst system (central-western sicily, Italy). Acta Carsologica, 40 (1): 53-64.

Millero F.J., Hubinger S., Fernandez M. \& Garnett S., 1987 - Oxidation of $\mathrm{H}_{2} \mathrm{~S}$ in seawater as a function of temperature, $p H$ and ionic strength. Environmental Science \& Technology, 21: 439-443. http://dx.doi.org/10.1021/es00159a003 
Mußmann M., Schulz H.N., Strotmann B., Kjar T., Nielsen L.P., Rossellò-Mora R.A., Amann R.I. \& Jorgensen B.B., 2003 - Phylogeny and distribution of nitratestoring Beggiatoa spp. in coastal marine sediments. Environmental Microbiology, 5: 523-533.

Nelson D.C., Jorgensen B.B. \& Revsbech N.P., 1986 - Growth pattern and yield of chemoautotrophic Beggiatoa sp. in oxigen-sulfide microgradients. Applied and Environmental Microbiology, 52: 225-233.

Peck S.B., 1986 - Bacterial deposition of iron and manganese oxides in north American caves. Speleological Society Bulletin, 48: 26-30.

Preisler A., de Beer D., Lichtschlag A., Lavik G., Boetius A. \& Barker Jorgensen B., 2007 - Biological and chemical sulfide oxidation in a Beggiatoa inhabited marine sediment. The ISME Journal, 1: 341-353.

Principi P., 1931 - Fenomeni di idrologia sotterranea nei dintorni di Triponzo (Umbria). Grotte d'Italia, 5: 1-4.

Sarbu S.M., Kane T.C. \& Kinkle B.K., 1996 A chemoautotrophically based cave ecosystem. Science, 28: 1953-1955.

http://dx.doi.org/10.1126/science.272.5270.1953
Sarbu S.M., Galdenzi S., Menichetti M. \& Gentile G., 2000 - Geology and biology of the Frasassi Caves in Central Italy, an ecological multidisciplinary study of a hypogenic underground ecosystem. In: Wilkens D., Culver D. \& Hamphreys W.F. (Eds), Ecosystem of the World, Subterranean Ecosystem. New York, Elsevier: 359-378.

Sayama M., Risgaard-Petersen N., Nielsen L.P., Fossing H. \& Christensen P.B., 2005 - Impact of bacterial $\mathrm{NO}_{3}$ transport on sediment biogeochemistry. Applied and Environmental Microbiology, 71: 7575-7577.

http://dx.doi.org/10.1128/AEM.71.11.7575-7577.2005

Schwedt A., Kreutzmann A.C., Polerecky L. \& SchulzVogt H.N., 2012 - Sulfur respiration in a marine chemolithoautotrophic Beggiatoa strain. Frontiers in Microbiology, 2: article 276.

Temara A., De Ridder C., Kuenen J.G. \& Robertson L.A., 1993 - Sulfide-oxidizing bacteria in the burrowing echinoid, Echinocardium cordatum (Echinodermata). Marine Biology, 115: 179-185.

http://dx.doi.org/10.1007/BF00346333

Yekta S.S., 2011- A model study of the effects of sulfideoxidizing bacteria (Beggiatoa spp.) on phosphorus retention processes in hypoxic sediments: Implications for phosphorus management in the Baltic Sea. Boreal Environment Research, 16: 167-184. 